\title{
ARTICLES
}

\section{Freedom of Religion, Inc.: Whose Sovereignty?}

\author{
Jean L. Cohen
}

Proliferating demands by the religious for exemptions from general valid law in the US and elsewhere should give us pause. Freedom of religion is the slogan, 'accommodation' the key claim. ${ }^{1}$ We seem to be in multicultural territory. 'Accommodation' implies that at issue is the protection of religious minorities from unduly burdensome laws passed by secularist or religious majorities. But I argue that the multicultural minority rights frame cannot get at the deep structure of the most contentious demands for accommodation by courts and legislatures, nor help us thematize the fundamental challenge they pose to liberal constitutional democracy.

Current 'freedom of religion' discourse assumes that religion is special and unique, quite apart from minority and majority statuses. And the demands I have in mind have little to do with tolerance or fairness. One much discussed problem is that 'accommodation' - grants of immunity and blanket exemptions from civil law - may turn unjust discrimination by or within religious organizations into a religious group right. At issue are exemptions for the religious (and their associations and enterprises) from legislation involving civil rights, employment discrimination, public health, and fair labour standards - exemptions that accommodate religious authorities and some individuals at the expense of the rights of others. But there is another, related stake in 'freedom of religion' talk: sovereignty. We face a twenty-first-century version of much older periodically resurrected tropes - freedom of religion and legal pluralism, invoked to challenge the comprehensive jurisdiction of civil law, derided as 'absolutist monistic sovereignty', this time of the liberal democratic constitutional state. Indeed, what makes religion unique for the accommodationist is the presupposition of another and higher source of law ascribed a dignity that requires recognition, deference and 'inter-sovereign respect'. ${ }^{2}$ Claims of immunity for the religious are often framed in terms of rights, but at issue is no ordinary conflict of liberal rights. Instead, assertions of unique prerogatives of autonomy (from regulation by civil

1 The US constitution's First Amendment states: 'Congress shall make no law respecting the establishment of religion or prohibiting the free exercise thereof'. In the mid-twentieth century, this was applied to the states. Accommodation claims invoke the free exercise clause and a federal statue, the Religious Freedom Restoration Act ('RFRA'), which reads as follows: the 'Government shall not substantially burden a person's exercise of religion even if the burden results from a rule of general applicability' unless (1) the burden is necessary for the 'furtherance of a compelling government interest' and (2) the government action at issue serves as the 'least restrictive means of furthering that compelling governmental interest'. 42 U.S. Code $\S \S 2000 \mathrm{bb}-1$ (a), (b).

2 Elizabeth Clarke, 'Religions as Sovereigns: Why Religion is Special', Bepress online publication February 2013 (available at <http://works.bepress.com/elizabeth_clark/16>). 
law) and corporate self-government (effective law-making immune to civil oversight) for religious associations and the non- or for-profit corporations owned or controlled by the religious have a deep structure of presumed jurisdictional prerogative that poses a serious challenge to liberal democratic understandings of constitutionalism, justice, sovereignty, and legitimacy of the civil state. My focus in this article is on the logic underlying a new wave of successful accommodation claims that involve exceptions from valid general laws required by a liberal conception of justice (such as those prohibiting or preventing status based employment discrimination) - exemptions that impinge on the rights of others and harm them, establishing privileges and immunities exclusively and uniquely for the religious, challenging the bases of liberal democratic constitutionalism. These differ from accommodations meant to protect the religious from majority injustice or insensitivity. First Amendment or statutory protections of religious individuals and minorities from discrimination, repression, targeting, intolerance and insensitivity by legislative majorities, courts or other groups are as important as those protecting against racial, gender, or any status group-based injustice. It may well be that case-specific exemptions crafted by legislatures and enforced by courts are appropriate to preclude or counteract such injustices. Liberal democratic principles suggest that lawmakers consider the normative value of everyone's ethical integrity when regulating or legislating. ${ }^{3}$ This paper leaves those sorts of accommodations aside in order to focus on the recent developments in religious freedom discourse and jurisprudence that subtly shift the problematic from justice to jurisdiction and shield religious groups from state scrutiny of practices involving harms to others and/or unequal and unfair discriminatory treatment of individuals in their employ or control.

I begin by (1) discussing two recent and momentous US Supreme Court cases: one from 2012 that foregrounds freedom and autonomy of 'the church' over an employment discrimination charge levelled in civil court by a school teacher; the other decided in June 2014, involving religious freedom claims of three for-profit corporations invoked to justify their demands for exemption from health care legislation requiring insurance coverage of certain contraceptives for women. ${ }^{4}$ Both revive an old trope regarding religious autonomy - the privileged and unique status of the corporate religious community regarding self-government and employment decisions. (2) I then review arguments as to why religious freedom and/or the freedom of religious conscience uniquely require exemptions from valid general law. The relevant 'freedom of religion' arguments fuse rights talk with jurisdiction talk reminiscent of late medieval conceptions of corporate privileges and immunities and evocative of early twentieth-century British pluralist conceptions of the polity. Indeed, the point is to challenge the supremacy and comprehensive scope of 'monistic' state sovereignty in the name of 'pluralism':

3 Ethical integrity concerns cannot be restricted to the religious. See Paul Bo-Habib, 'A Theory of Religious Accommodation', Journal of Applied Philosophy 23(1) (2006): 109-126.

4 Hosanna-Tabor Evangelical Lutheran Church and School v. EEOC et al., 132 S. Ct. 694, 181 L. Ed. 2d 650 (2012); Burwell, Secretary of Health and Human Services, et al. v. Hobby Lobby Stores, Inc., et al., 573 U.S. (2014). 
legal, associative, and political. Religion is deemed special and unique on the contemporary jurisdictional religious pluralist approach because it involves a distinctive conception of autonomy linked to a sovereignty claim. (3) I examine the religionists' critique of state sovereignty and their attempts to enlist liberal-pluralist principles to justify it. I argue that we confront a challenge to, rather than an extension of, liberal freedom, democratic legitimacy and the pluralism liberal democracy presupposes. The project is to shift from what under liberal democratic constitutionalism have become questions of justice back to issues of jurisdiction, thereby enhancing and shielding religious communities' prerogatives in law-making from civil oversight. What does the work in these analyses, as I shall show, is a political-theological conception of the corporate and of sovereignty. (4) I conclude with counter arguments about democratic sovereignty, liberal democratic constitutionalism, justice, plurality, and rights. I show that the version of 'freedom of religion' discourse proliferating in the US and influencing the Court involves the assertion of privileges and immunities from civil and constitutional law, not equal rights or fair treatment under that law, thus undermining rather than being the paradigm of liberal rights, and threatening the achievements of democratic constitutionalism. (5) While the accommodation discourse I address is context specific, the underlying justifications and ideology asserting jurisdictional pluralism and church autonomy are not dependent on US constitutionalism and indeed are being asserted on a global level under the 'freedom of religion' slogan. This poses challenges to civil democratic states everywhere.

\section{Ominous court cases}

The jurisdictional pluralist push for accommodation is not new. ${ }^{5}$ But the recent success in the highest court of a version that construes religion and religious communities as special and unique, entitled to deference from the state regarding legal claims to autonomy is striking. While both cases involve employment discrimination issues, the contexts are distinct: one involving a church-owned school, the other a for-profit business. Yet the decisions are based, I argue, on shared, and in my view highly problematic, assumptions regarding the rights of the corporate religious to exemption from federal civil rights laws (and regulatory oversight by the Equal Employment Opportunity Commission) that forbid certain types of discrimination in employment (on the basis of disability and gender respectively). ${ }^{6}$ At issue are thus exemptions from laws required by liberal justice

5 Michael W. McConnell, 'Accommodation of Religion', The Supreme Court Review 1985 (1985). See also Douglas Laycock, 'Regulatory Exemptions of Religious Behavior and the Original Understanding of the Establishment Clause', Notre Dame Law Review 81 (2006).

6 See, e.g., Title VII of The Civil Rights Act of 1965, 42 U.S.C. $§ \S 2000 \mathrm{e}-2$ et seq. ('CRA') (forbidding employment discrimination on the basis of race, color, religion, gender, and national origin) and the Americans with Disabilities Act of 1990 ('ADA'), 42 U.S.C. $\S \S 12101$ et seq. The provisions of these statues grant the EEOC enforcement powers under 42 U.S.C. $\S 2000$ e-5 (1964) (CRA) and 42 U.S.C. $§ 12117$ (1990) (ADA). 
that involve harms to others, basic equality issues, and fundamental public purposes of the state.

\subsection{Freedom of religion as church autonomy}

In its 2012 unanimous opinion in Hosanna-Tabor Evangelical Lutheran Church and School v. E.E.O.C. et al., the Court constitutionalized the concept of ministerial exception for the first time, applying it globally to 'the church', shielding it from liability under the Americans with Disabilities Act for a retaliatory dismissal of an employee, Perich, who taught mainly secular subjects in a religious school. ${ }^{7}$ The issue was employment discrimination by a religious organization and its nonprofit entities. Title VII of the 1964 Civil Rights Act prohibits employment discrimination on the basis of race, colour, religion, sex, or national origin, but exempts religious entities that hire on the basis of religion. ${ }^{8}$ As amended in 1972, Section 702 of the Act broadened this exemption to include religious corporations, associations, educational institutions and societies, permitting them all to discriminate in favour of coreligionists. ${ }^{9}$ Technically, this means that religious employers could be sued for racial or gender discrimination and under other laws barring discrimination on the basis of age or disability. But the 1972 amendment made it easier for employers to frame discrimination as a religious requirement, and it broadened the scope well beyond churches and religious schools. Moreover, it dropped the requirement that religious organizations may discriminate on the basis of religion only in relation to their religious activities. In an infamous 1987 case in which a janitor working in a gymnasium open to the public but owned by the Mormon Church was, because he was not Mormon, fired after 16 years of employment, the Court upheld Section 702 and the discretionary exemption it accords exclusively to religious associations. ${ }^{10}$ Moreover, it refused to inquire into the religious vs. secular nature of the job on the grounds that only the religious, and not secular courts could make such a determination! Congress and the Court eliminated the obligation on the part of religious employers to make the case that their discriminatory practices are required by their faith. ${ }^{11}$

It is thus hardly surprising that lower courts have generally refrained from holding churches liable for their hiring and employment practices, or that Court rulings prior to 2012, permitted discrimination on the basis of religion by religious

7 Hosanna-Tabor Evangelical Lutheran Church and School v. E.E.O.C. et al., 132 S. Ct. 694, 181 L. Ed. 2d 650 (2012). The ADA prohibits an employer from discriminating against a qualified individual on the basis of disability and prohibits an employer from retaliating against any individual who reports such an act to the EEOC. 42 U.S.C. $\S \S 12101,12203$.

842 U.S.C. $\S \S 2000 \mathrm{e}-1$ (a).

9 Ibid.

10 Corp. of Presiding Bishop v. Amos, 483 U.S. 327 (1987).

11 For a critique of the Amos ruling, see Nancy L. Rosenblum, 'Amos: Religious Autonomy and The Moral Uses of Pluralism', in Obligations of Citizenship and the Demands of Faith, ed. Nancy L. Rosenblum (Princeton: Princeton University Press, 2000), 170-1. 
organizations. ${ }^{12}$ But Hosanna-Tabor was the first time the Court considered whether the freedom of a religious organization to select its ministers is implicated in a suit charging employment discrimination on other grounds. ${ }^{13}$ The Court found a ministerial exception in the First Amendment free exercise and establishment clauses that bar 'interference' by the state in 'the church'. ${ }^{14}$ It held that the church's determination of the employee's status as a minister was dispositive of her employment status in the church owned school, marginalizing the relevance of her secular teaching functions. The invention of the ministerial exception as a constitutional commitment is a radical shift in the logic of 'accommodation'. Why?

The Court's rhetoric gives the clue. Deeming freedom of association rights insufficient to protect expressive purposes in selecting ministers, the Court held that the First Amendment acknowledges religion to be special with respect to religious organizations' autonomy. The Equal Employment Opportunity Commission (EEOC) and Perich acknowledged that employment discrimination laws would be unconstitutional as applied to religious groups in certain circumstances such as compelling the ordination of women by the Catholic Church or by an Orthodox Jewish Seminary. According to the EEOC, religious organizations could successfully defend against employment discrimination claims in those circumstances by invoking the constitutional right to freedom of association implicit in the First Amendment. The EEOC and Perich thus saw no need and no basis for a special rule for ministers grounded in the religion clauses. ${ }^{15}$ The Court found this position untenable because the right to freedom of association is a right enjoyed by religious and secular groups alike, implying that the First Amendment analysis should be the same whether the association in question is the Lutheran church, a labour union or a social club. According to the Court,

[t]hat result is hard to square with the text of the First Amendment itself, which gives special solicitude to the rights of religious organizations. ${ }^{16}$

But the First Amendment never mentions the rights of religious organizations. On the Court's reading, the religion clauses construe religious association not as only special (particularly vulnerable to state based discrimination or coercion),

12 Leslie C. Griffin, Law and Religion: Cases and Materials, 3rd ed. (New York: Foundation Press, 2013), 202-10. Lower courts' decisions gave rise to the idea of a ministerial exception. In a number of church property dispute cases, the Court ceded jurisdiction to the Church's highest ecclesiastical tribunals.

13 'Until today, we have not had occasion to consider whether this freedom of a religious organization to select its ministers is implicated by a suit alleging discrimination in employment'. Hosanna-Tabor, 132 S. Ct. at 705, 181 L. Ed. 2d at 663. The ADA prohibits retaliation against employees complaining about potential discrimination to the EEOC.

14 Hosanna-Tabor, 132 S. Ct. at 697, 181 L. Ed. 2 d at 654.

15 Ibid., 663-4. Notably, the Court cited the briefs of the parties, both of which refer to Roberts $v$. United States Jaycees, 468 U.S. 609, 622 (1984), which holds that a right to freedom of association can be found in the First Amendment. 
but as unique, and portray the needs and requirements of church autonomy as radically distinct from those of any other form of association. ${ }^{17}$ Accordingly, 'the Church' must be free to choose those who will guide it on its way. At stake, Chief Justice Roberts argued, is no mere employment decision - but the 'internal governance of 'the Church'. ${ }^{18}$

As Justice Alito notes in his concurrence, Hosanna-Tabor discharged Perich because she threatened to file suit against the church in a civil court and this apparently contravened the Lutheran doctrine that disputes among Christians should be resolved internally without resort to the civil court system! ${ }^{19}$ Perich argued that this doctrine of internal dispute resolution was a mere pretext for her firing, which was really done for non-religious reasons. But Justice Alito argues that Courts are barred from entering into a pretext inquiry because this would undermine religious autonomy and the right of the church to its own internal dispute resolution mechanisms, including the creation of its own tribunals to resolve such conflicts. Thus, the ministerial exception now apparently bars 'ministers' of religious institutions from filing suits for any form of job discrimination. In so constitutionalizing the concept of ministerial exception, the Court opened the door to extending it well beyond the selection of the ministers of a religious congregation. ${ }^{20}$

This 'ministerial exception' now covers employees such as teachers and pianists working in religious institutions and non-profit organizations - whether or not they are actually clergy. Following quickly upon the heels of the Hosanna-Tabor decision, a federal appeals court invoked the ministerial exception to bar a pianist, who had no ministerial training or duties, from bringing suit for age discrimination and wrongful dismissal against the Catholic Church that employed him. ${ }^{21}$ Recently, Archbishop Cordileone declared teachers in catholic schools in San Francisco should be designated part of the ministry, despite acknowledging that not all of them are catholic, thereby placing them out of the reach of federal antidiscrimination laws while simultaneously forbidding them from publically chal-

17 Religious organizations endanger civil republics, as the establishment clause implicitly acknowledges. See James Madison, 'A Memorial and Remonstrance Against Religious Assessments, June 20, 1785', in Selected Writings of James Madison, ed. Ralph Ketcham (Indianapolis: Hackett Pub., 2006), 21-26.

18 Hosanna-Tabor, 132 S. Ct. at 706-7, 181 L. Ed. 2d. at 663-4.

19 Ibid., 673 (Alito, J., concurring). Despite the Court's refusal to interpret religious doctrine, Justice Alito cites a biblical text, 1 Corinthians 6:1-11, as ground for the church's policy that Christians should settle disputes among Christians rather than to take those disputes before the 'ungodly' for judgment. Ibid., n. 5.

20 See ibid., 668. The Court tried to circumscribe its holding 'to this minister in this case', stating that 'we express no view on whether the exception bars other types of suits, including actions by employees...there will be time enough to address the applicability of the exception to other circumstances if and when they arise'. 710, 688.

21 Philip Cannata v. Catholic Diocese of Austin, et al., slip op., no. 11-51151 (5th Cir. Oct. 24, 2012). Cannata filed suit under the Americans with Disabilities Act, 42 U.S.C. $\S \S 1201$ et seq., and the Age Discrimination in Employment Act, 29 U.S.C. $\$ \S 621$ et seq. Clearly the Court failed in its efforts to circumscribe. 
lenging church teachings on homosexuality and contraception. ${ }^{22}$ The Roberts Court thus carved out areas of jurisdiction for churches in their corporate character, construed as a hierarchy or as a community of believers, over a wide range of persons, subject matters and institutions. ${ }^{23}$ Indeed it cast religious associations (and their non-profit organizations) as so special and unique that they enjoy privileges of autonomy (to make their own rules, and to be exempt from the rules of civil law and regulatory oversight by public powers) well beyond what other civil associations enjoy under the First Amendment and in any liberal constitutional democracy. How can one account for this?

Indeed, it seems to conflict with the Court's notorious 1990 ruling in the Smith case which rejected the free exercise claim of two native Americans who lost their jobs for using peyote, an illegal substance, in a religious ceremony. ${ }^{24}$ The Court denied that individuals have a (unique) constitutional right to exemptions from generally valid neutral laws that impinge on their religious practice, even if the effect is to outlaw sacramental acts of worship. ${ }^{25}$ It argued that such a constitutional right would make the individual's conscience a law unto itself, although it stated that legislatures are permitted to grant selective accommodations to religious groups when crafting laws. On the Smith ruling, then, there is no individual right of religious autonomy. Individuals have no constitutional entitlement to follow the dictates of their religion free from state regulation. Thus one cannot account for the autonomy ascribed to 'the church' in Hosanna-Tabor by arguing that it is a carryover of an entitlement held by individual believers into their voluntary religious associations where they express and act upon their religious understandings.

The Roberts Court addressed its ruling's apparent inconsistency with Smith by declaring that unlike government regulation 'of only outwards physical acts' such as an individual's ingestion of peyote, selection of its ministers involves an internal decision that affects the faith and mission of 'the church' itself. ${ }^{26}$ This tendentious distinction is preceded by a curious and telling genealogy that frames First Amendment protection of freedom of religion in terms of the old jurisdictional battles between church and state in early modern England. Accordingly, the Church was 'free' in the thirteenth century thanks to the 1215 Magna Carta signed by King John, but lost its freedom with Henry VIII's Act of Supremacy of

23 The Court frames the ministerial exemption as an affirmative defense on the merits, not as a jurisdictional bar. But its reasoning is tantamount to acknowledging a unique domain of jurisdiction and an extraordinary privilege of autonomy for religious organizations, denied to other associations. In effect it treats the ministerial exception as a kind of forum selection clause that would, if presented before a civil court, confine certain disputes to internal church decisionmaking institutions. See Hosanna-Tabor, 132 S. Ct. at 709, 181 L. Ed. 2d. at 667 n. 4.

24 Employment Division, Department of Human Resources of Oregon v. Smith, 494 U.S. 872 (1990).

25 Smith, 494 U.S. at 872. For a discussion, see The Immanent Frame: Secularism, Religion and the Public Sphere; Rethinking Secularism; 'The Church', website essay by Winnifred Fallers Sullivan, January 31, 2012.

26 Hosanna-Tabor, 132 S. Ct. at 697, 181 L. Ed. 2d. at 655. 
1534. ${ }^{27}$ The American founders were allegedly reacting against the latter and reinstating the former when they crafted the First Amendment. ${ }^{28}$

What this story subtly resurrects is the old 'two worlds' theory of separate jurisdictional domains divided between two autonomous (and as we shall see mystical) corporate bodies and sovereigns - Church (God) and State (King). This twoworld theory of jurisdictional separation is Christian and theological, premised on the idea that the ultimate source of authority for both realms (regnum and sacerdotium) is God. ${ }^{29}$ Its revival implicitly challenges the modern sovereign state's supremacy over 'the Church' along with the state's monopoly of coercive law making. ${ }^{30}$ It also throws down the gauntlet to the principle of democratic legitimacy that frames the people and their representatives as the sole authoritative source of legitimate coercive law. The two-world theory is the basis of the distinctive jurisdictional version of accommodation and separation involving corporate immunity from public law - 'libertas ecclesia' (freedom of the church) - that is now being resurrected to justify a broad constitutionalized right to 'church autonomy' - exemption from valid civil law and state regulation of self-regulation. ${ }^{31}$ 'The Church', the dominant trope in Chief Justice Robert's opinion, is seen as a corporate body, autonomous vis-à-vis secular government, and uniquely entitled to 'accommodation' - i.e., privileges and immunities from public law, deference to its internal hierarchies, authority, law-making and governance over persons and subject matters in its remit. ${ }^{32}$

\subsection{Freedom of religion for for-profit corporations}

The Court had never addressed religious exercise claims of for-profit corporations. In Burwell v. Hobby Lobby Stores, Inc., ${ }^{33}$ it therefore first had to decide the threshold question of whether for-profit corporations qualify as 'persons' with

27 Ibid., 659-61. Roberts' opinion cites Michael W. McConnell, 'The Origins and Historical Understanding of Free Exercise of Religion', Harvard Law Review 103 (1990), among others, in presenting this genealogy of the First Amendment free exercise clause.

28 The Immanent Frame, website essay by Winnifred Fallers Sullivan.

29 Steven Smith, The Disenchantment of Secular Discourse (Harvard University Press, 2010), 113-5. See the text accompanying n. 138, infra.

30 This has long been the stance of Michael McConnell. See McConnell, 'Accommodation of Religion', and Michael W. McConnell, 'Accommodation of Religion: An Update and a Response to Critics', George Washington Law Review 60 (1992). For an earlier legal pluralist attempt at resurrecting what amounts to neo-medievalism see John Neville Figgis, Churches in the Modern State (London: Longmans, Green and Co., 1913).

31 Figgis, Churches in the Modern State, 123; Carl H. Esbeck, 'A Religious Organization's Autonomy in Matters of Self-Governance: Hosanna-Tabor and the First Amendment', Engage 13 (2012); Douglas Laycock, 'Church Autonomy Revisited', The Georgetown Journal of Law and Public Policy 7 (2008): 253-78; Douglas Laycock, 'Towards a General Theory of the Religion Clauses: The Case of Church Labor Relations and the Right to Church Autonomy', Columbia Law Review 81 (1981): 1373-1417. See also the Church Autonomy Conference, Brigham Young Law Review 2004/4 (2004).

32 See Clark, 'Religions as Sovereigns'.

33573 U.S. (2014) (slip op.). 
free exercise rights under the law. ${ }^{34}$ At issue are regulations promulgated by the Department of Health and Human Services (HHS) under the Patient Protection and Affordable Care Act passed by Congress in 2010 (ACA), which requires employers' group health plans to furnish preventive care and screenings for women without any cost sharing requirements, including coverage for the twenty contraceptive methods approved by the Food and Drug administration. ${ }^{35}$ The ACA exempted religious institutions - churches - from the contraceptive mandate. HHS went further, accommodating religious non-profit organizations with religious objections to providing contraceptive coverage by requiring that the relevant insurance issuer exclude contraceptive coverage from the employer's plan and offer plan participants separate payments for contraceptive services with no added cost sharing to the employer or employee. ${ }^{36}$ 'Eligible organizations' for this accommodation by HHS are any non-profit that 'holds itself out as a religious organization' and 'opposes coverage for some of all of any contraceptive services required to be covered...on account of religious objections'. ${ }^{37}$ To qualify for this accommodation, the employer must certify that it is such an organization. The question in Hobby Lobby was whether for-profit business corporations might also qualify for a religious exemption under the Religious Freedom Restoration Act ('RFRA') and indirectly, the First Amendment. Having decided the threshold question in the affirmative, the Court then had to go through the RFRA formula to assess whether the law substantially burdens religious exercise of the relevant persons and, if so, whether it used the least restrictive means in furthering a compelling state interest. The obvious clash here is between the religious interests of the controlling stockholders of these corporations and their women employees' rights to health care, gender equality, and religious freedom. Note that the petitioners, three for-profit corporations, are neither religious membership organizations nor affiliated with any church. ${ }^{38}$ Nevertheless, the Court ruled that for 'closely-held' corporations, the HHS regulations imposing the contraceptive mandate violate RFRA.

The controlling stockholders of all three corporations believe that life begins at conception and that it would violate their religion to facilitate access to contraceptive drugs or devices that operate after that point. ${ }^{39}$ They invoked their reli-

34 They have long qualified as persons under constitutional law for certain purposes. At issue here are religious freedom claims under RFRA. See, e.g., Joshua Barkan, Corporate Sovereignty: Law and Government under Capitalism (Minneapolis: University of Minnesota Press, 2013), 67-82.

35 Hobby Lobby, 573 U.S. at 1-2 (syllabus).

36 Ibid.

37 Ibid., 9.

38 Hobby Lobby is a nationwide chain comprised of 500 stores and more than 13,000 employees. It is organized as a for-profit corporation under Oklahoma law. Mardel is a for-profit corporation under Oklahoma law, operating 35 bookstores employing nearly 400 people. Both are 'family businesses' owned and operated by the Greens and their children. Ibid., 13-14. Conestoga Wood Specialties is a for-profit business organized as a corporation under Pennsylvania law and is owned by the Hahns. Ibid., 11-12.

39 Ibid., 14-15. The petitioners are religious 'integralist' seeking to live all aspects of their life (personal, religions, work related, etc.) under their religious law. 
gious freedom under RFRA, arguing transitivity onto the corporation itself. Yet the point of incorporating a business is to set up an autonomous entity legally distinct from its stockholders. It provides advantages like limited liability and a corporate veil that separates the rights and obligations of the incorporators from the corporate entity itself. The petitioners, however, want to have it both ways: to retain the economic advantages of the corporate veil while also piercing it for their personal religious purposes, ascribing their individual free exercise rights to the autonomous corporate entity.

The ascription of legal personhood and constitutionally protected rights to corporations is not new. ${ }^{40}$ But while they may be legal persons for certain constitutional purposes, it is a radical step to deem for-profit business corporations persons capable of exercising religion. This standing issue was thus a key conundrum facing the Court. HHS argued that companies could not sue under RFRA because they are for-profit corporations and that the owners cannot sue because the regulations apply only to the companies and not to the owners as individuals. ${ }^{41}$ The religious freedom of the owners of the for-profit corporations is not at stake and the latter, although deemed persons under the law for certain purposes, do not have free exercise rights of their own. The Court maintained that such a stance would leave people with a difficult choice: either give up the right to seek judicial protection of their religious liberty or forgo the benefits of operating as corporations. ${ }^{42}$ It ruled that corporate personhood does not bar the religious from operating the business corporations and the corporate funds they control in ways congruent with their religion. Just which conception of the corporate personality is doing the work in this decision is thus well worth reflecting upon. I argue that a political theological conception of the corporate underlies both this and the HosannaTabor rulings.

The second conundrum involved the questions of whether the law imposed a substantial burden on the relevant persons' freedom to exercise their religion, whether it furthers a compelling government interest, and whether the law used the least restrictive means in fulfilling that purpose. But here too the question of which persons are relevant in the assessment and whose rights are at stake and at risk of being unconstitutionally burdened arises. The free exercise rights of 'owners' of the corporation, and/or the rights ascribed to the corporate person, seem pitted against the rights of its female employees - to health care and to religious freedom. Does the decision not in favour of the corporation's stockholding family put employees to an even more difficult choice: either to forgo their jobs or forgo access to health care coverage of their reproductive choices to which they have every right? Is it not a slight of hand to treat for-profit corporations as if they were religious associations? Again much seems to turn on the conception of the corporation doing the work here. 
John Dewey argued long ago that neither the legal concept of corporate personhood, nor the particular conception of the personality of the corporation that one imports into the law on their own, determine the scope of corporate powers. ${ }^{43}$ There are conflicting conceptions of corporate personhood, but none are dispositive regarding corporate rights: the nature and scope of corporate prerogatives, privileges, and powers is a political issue, not one of legal form. ${ }^{44}$ Nevertheless, indeterminacy does not mean that there is no strategic use of concepts on the part of jurists, or that there is not an elective affinity between a particular conception and particular doctrinal outcomes...on the contrary. ${ }^{45}$ While the context does constrain the utility of specific conceptions, these conceptions may also have intrinsic limits and their own if thin normative purchase. ${ }^{46}$ To see what is really doing the work here, it is thus well worth looking into the conception of the corporate person deployed in the majority opinion and in the dissent and then reflecting on the unstated conceptions of the corporate and of sovereignty imported into both.

According to Justice Alito's majority opinion, for-profit corporations qualify as 'persons' enjoying the freedom of religion protections articulated in RFRA and, by extension, the First Amendment. But since corporations have no conscience, beliefs, or feelings, it seems counter-intuitive that they could either exercise religion or have their religious freedom unduly restricted by law. Justice Alito resolves this dilemma by (1) apparently relying on a 'nexus of contracts' conception of the corporation; (2) stressing the 'closely held' character of the corporations at issue in this case; and (3) disputing any constitutive difference between non- and for-profit corporations regarding religious exercise.

The 'nexus of contracts' theory of corporate personhood holds that the corporation is a network of reciprocal agreements among private individuals who collaborate to pursue a common goal along with their individual purposes and interests. The hierarchical decision structure typical of most corporations serves a coordination function relieving people from the burden of having to bargain continuously over day-to-day decisions, thereby reducing the transaction costs of shareholders and executives. ${ }^{47}$ Corporations are seen as 'voluntary associations' of individuals who contractually participate in them and thereby 'consent' to their governance structures. Yet they are nonetheless deemed legal persons insofar as they own property, may contract, sue and be sued in court as a unitary entity. As a legal person, and as a contracting individual, the corporation is distinct from its share-

43 John Dewey, 'The Historic Background of Corporate Legal Personality', Yale Law Journal 35 (1926): 655-73.

44 Ibid., 656, 663-4, 669.

45 See Morton J. Horwitz, 'Santa Clara Revisited: The Development of Corporate Theory', West Virginia Law Review 88 (1985): 223-4.

46 See James D. Nelson, 'Conscience, Incorporated', Michigan State Law Review (2013): 1573.

47 Kate Jackson points out in 'More Taliban than Torquemada: Illiberal Implications of Hobby Lobby's Right to Free Exercise', (Thesis, Columbia University, 2014): 3 n. 4 (ms. on file with author), that these default rules contain provisions that favor executives and shareholders by reducing their respective collective action costs. They decline to do the same for employees. 
holders who thus gain the advantages of limited liability, asset lock-in and entity shielding. This is what distinguishes the corporation from a partnership or other groupings. ${ }^{48}$ Nevertheless, on the aggregate 'nexus of contracts' vision of the corporation, its personhood is in certain respects nominalist: accordingly the rights and duties of the incorporated association are in reality the rights and duties of the persons who compose it.

It is clear that Justice Alito's majority opinion in Hobby Lobby tries to rely on this conception of corporate personhood. He notes that a corporation is simply a form of organization used by human beings to achieve desired ends. ${ }^{49}$ Corporations are deemed persons by statutory and constitutional law, but it is important to keep in mind that the purpose of this fiction is to provide protection for human beings' ${ }^{50}$ Justice Alito notes that RFRA included corporations within its definition of 'persons', stating that '[a]n established body of law specifies the rights and obligations of the people (including shareholders, officers, and employees) who are associated with a corporation...When rights, constitutional or statutory, are extended to corporations, the purpose is to protect the rights of these people'. ${ }^{51}$ In response to the Third Circuit's statement that general business corporations do not exercise religion since, separate from the individual owners or employees, they do not pray, worship, or observe sacraments, and hence they have no RFRA rights, Justice Alito observed that separate and apart from the human beings who own, run and are employed by them, corporations cannot do anything at all. ${ }^{52}$

He also stresses the fact that the corporations at issue are 'closely held' family businesses both in order to strengthen the transitivity claim and to limit the scope of the decision to conjure the risk of myriad freedom of religion exemption claims by for-profit corporations. Accordingly, the corporations' personhood as interpreted on the nexus of contracts approach does not conflict with the claim that it is the religious freedom of the stockholders/executives that is at issue because the latter consist of a small number of family members who control the voting shares and direction of the respective corporations.

That these are for-profit corporations is dismissed as non-dispositive. It cannot be the corporate form per se that militates against ascribing RFRA protection to corporate persons, because non-profit corporations receive it. The Court also rejects the Dissent's argument, '...that non-profit corporations are special because furthering their religious 'autonomy'...often furthers individual religious freedom

David Ciepley, 'Neither Persons nor Associations: Against Constitutional Rights for Corporations', Journal of Law and Courts 1 (Fall 2013): 228. See also Horwitz, 'Santa Clara Revisited' and Turkuler Isiksel, 'The Rights of Man and the Rights of the Man-Made: Corporations and Human rights', paper presented at the American Political Science Association Annual Meeting, Washington, D.C., August 28-31, 2014: 22 (ms. on file with author).

50 Ibid.

51 Ibid.

52 Ibid., 18-19. 
as well'. ${ }^{53}$ Justice Alito maintains that this principle applies equally to for-profit corporations: 'Furthering their religious freedom also furthers individual religious freedom' ${ }^{54}$ Since the owners of these 'closely held' corporations seek to perpetuate their religious values and operate them in the manner that reflects their religious heritage, the Court sees no distinction between non- and for-profit corporations that makes a relevant legal difference. It is tautological, he notes, that for-profit corporations are profit seeking. They may have other charitable and religious aims, thus drawing a sharp line between for- and non-profit corporations is misleading.

The rest of the opinion pursues the RFRA formula. It argues that non-compliance with the HHS mandate could have serious economic consequences for the Hahns and the Greens (the controlling stockholders) and thus the mandate seriously burdens their religious exercise. To comply, they would have to facilitate actions on the part of their women employees who exercise the right to use the 'objectionable' forms of contraception. ${ }^{55}$ Justice Alito is willing to assume that the contraceptive mandate serves a compelling interest in ensuring that all women have access to all FDA-approved contraceptives without cost sharing. ${ }^{56}$ But on balance the religious freedom of the stockholders trumps. ${ }^{57}$

As Justice Ginsberg intimates in her sharp dissent, the Court's reliance on the nexus of contracts theory is at best misleading, not least because it fails to account for why the religions of workers are not similarly transposed onto the corporation. ${ }^{58}$ Justice Ginsberg relies on a different conception of the corporation - the concession theory. ${ }^{59}$ She cites former Chief Justice Marshall: '...a corporation is an artificial being, invisible, intangible and existing only in contemplation of law'. ${ }^{60}$ Accordingly, as 'mere creatures of the law' corporations have only those rights and attributes of legal personhood that the state through its laws of incorporation chooses to grant. To be sure, the concession theory dominant in American law prior to the second part of the nineteenth century referred to corporate charters granted by the states to specific groups of individuals to serve

53 Ibid., 21.

54 Ibid. That the HSS exemption for non-profit corporations holding themselves out to be religious might have been a mistake and a legal error as I believe, is never addressed by the Justices.

55 Ibid., 36.

56 Ibid., 39-40 (note that Justice Alito puts 'gender equality' and 'public health', the terms of the HSS mandate, in scare quotes).

57 Because the government could have assumed the cost of the four contraceptives, it allegedly did not use the 'least restrictive means' required under RFRA. Yet it is not up to courts to devise governmental programs. Thanks to the decision the employees now have no coverage for the relevant contraceptives.

58 No statutory incorporation law states that shareholders 'own' the corporation. It is debated whether stockholders 'own' the corporation and questionable whether they have a superior claim over employees when it comes to transposing their interests.

59 See Horwitz, 'Santa Clara Revisited', 173, 181 and Dewey, 'The Historic Background of Corporate Legal Personality', 666-8.

60 Hobby Lobby, 573 U.S. at 14 (Ginsburg, J., dissenting); Trustees of Dartmouth College v. Woodward, 17 U.S. 518 (1819). 
public, and not only private purposes. ${ }^{61}$ Corporations on this model are brought into existence at the behest of the sovereign; their powers, including governance privileges, are delegated. ${ }^{62}$

With the late nineteenth century's general incorporation statutes, the conception of the corporation as a quasi-public entity created through particularized sovereign grants for public purposes lost its prominence. ${ }^{63}$ Nevertheless, the concession theory continues to be invoked in judicial doctrine to indicate that no matter how easy the process, it is still through state law that a corporation gains legal status, rights, and legal personality. ${ }^{64}$ The concession theory, like the nexus of contracts conception, construes corporate personality as a legal fiction. But on the former approach there can be no transposition of the rights of natural persons onto the corporate body. Justice Ginsburg thus invokes the concession theory to argue that the exercise of religion is characteristic of natural persons, not artificial legal entities, explaining the lack of precedent for ascribing religious freedom to for-profit corporations. ${ }^{65}$

But, what about religious accommodations of non-profit corporations? The Majority made much of this, inferring that it thus cannot be the corporate form itself that precludes accommodation. However, a crucial distinction is elided here, one which 'constantly escapes the Court's attention', namely 'between a community made up of believers in the same religion and one embracing persons of diverse beliefs'. ${ }^{66}$ Churches and non-profit religion-based organizations received accommodations not because they are non-profits, but because they are the affiliates of religious membership associations. For many, religious activity derives meaning from participating in a religious membership community, and in collective rituals. In such contexts, protecting the groups' religious exercise does further individual religious freedom. Accordingly, a religious organization's right to free exercise of religion arises from the interests of associated individual members. Crucially, religious associations exist to foster the interests of persons subscribing to the same religious faith, even if they do religious charitable work that helps others. The decisive feature of religious associations is thus not that they may also be organized as non-profit corporations, but that they are religious entities, existing to serve a community of believers. ${ }^{67}$ None of this holds true of forprofit corporations. Workers sustaining their operations are not drawn from one

61 Barkan, Corporate Sovereignty, 19-39.

62 Paraphrasing Barkan, Corporate Sovereignty, 52.

63 Barkan, Corporate Sovereignty, 28-57 discussing privatization of the corporation after general incorporation statutes ended the use of charters as regulatory tools. But general incorporation statues for churches in the early nineteenth century went together with intrusive state regulation of self-regulation for public purposes. See Sarah Gordon, 'The Place of the Faith: Religion and Property in American History', paper presented at the Institute for Religion, Law \& Public Life Lecture Series, Columbia University, November 14, 2014 (ms. on file with author). 
religious community. Indeed, by law no religion-based criteria can restrict the work force of business corporations ${ }^{68}$ Hobby Lobby and Conestoga would not be permitted to hire only persons who share the religious beliefs of their owners, the Greens or the Hahns. The point is that churches, religious institutions, and affiliated non-profits are protected by RFRA and the First Amendment not due to their non-profit, corporate character, but rather due to their features as religious membership bodies.

Indeed, recognition of the discrete characters of ecclesiastical and lay corporations dates back to Blackstone. ${ }^{69}$ As for the claim that closely held corporations are like sole proprietorships such as a kosher butcher who seeks to run the business in accord with his religious beliefs and is thus worthy of accommodation regarding Sunday closing laws, Justice Ginsburg insists that by incorporating a business, an individual separates herself from the entity and escapes personal responsibility for the entity's obligations. ${ }^{70}$ 'Closely held' is not synonymous with 'small', as proven by the size of Hobby Lobby, a chain store conglomerate with over 13,000 employees! ${ }^{71}$ The actions of third parties (employees) exercising their rights under civil law are not attributable to the controlling stockholders of the corporation and the latter have no plausible claim to have their external preferences (preferences about what others do with their salaries and insurance benefits) accommodated by the state.

Indeed, with respect to balancing required by RFRA, the dissent disputes that a substantial burden is placed on Hobby Lobby since they are not required to pay directly for contraceptives but to direct money into undifferentiated funds financing a variety of benefits. The decision whether to claim particular benefits is made by the covered employees. The latter may not share the religious beliefs of the Greens or the Hahns and it is their autonomous choice, not that of the stockholders, as to how to use their health insurance benefits. Moreover, and crucially, no prior decision under RFRA allows a religion-based exemption when the accommodation would be harmful to others - here, the very persons the contraceptive coverage requirement was designed to protect. $^{72}$ Yet granting a religion-based exemption to a commercial employer would operate to impose the employer's religious faith on the employees - just what the establishment clause is designed to prevent. ${ }^{73}$ The compelling interest of the state in women employees' health (not to mention their own freedom of religion regarding the choice of contraception) should trump the highly attenuated 'burden' on the Hahns and the Greens. ${ }^{74}$

The Dissent's focus on the employees of the for-profit corporation apparently strengthens the dis-analogy with religious non-profits because they are clearly

68 Ibid., 16-17.

69 Ibid., 18.

70 Ibid., 14 n. 13.

71 Ibid., 19.

72 Ibid., 27.

73 Ibid., 32 (citing United States v. Lee, 455 U. S. 252, 259 (1982)).

74 Ibid., 26-30. 
not members in the relevant sense of a religious association. Their affiliation with the corporation is a matter of wage earning and employment, not a statement of religious belief or identification with the religious purposes of the corporation's stockholders. ${ }^{75}$ Thus there is a 'special solicitude generally accorded non-profit religion-based organizations that exist to serve a community of believers, solicitude never before accorded to commercial enterprises comprising employees of diverse faiths' ${ }^{76}$ Accordingly the exemption afforded to religious non-profits should not be extended to for-profit corporations because one cannot align business corporations with religion-based organizations.

Clearly, the Dissent is also using concepts strategically. For the conception of the corporation, it deploys is indeterminate regarding the rights that supposedly follow from it. ${ }^{77}$ Under the concession theory, the corporation is just a legal construct via which the state constitutes and endows a collective entity with rights and duties. The theory is indifferent regarding the independent reality of a collective body or group yet it must insist that as a corporate entity, it and its legal powers and prerogatives are derived. ${ }^{78}$ This means that incorporation statutes could include religious accommodation, among the rights and privileges ascribed to corporations. The fact that this has not been done for for-profit corporations does not mean, that it could not be done.

But there is a deeper problem with the Dissent's approach. Much of Justice Ginsburg's argument turns on the distinctiveness of religious organizations that serve a community of believers. ${ }^{79}$ She cites the Court's 'special solicitude to the rights of religious organizations' reiterated in Hosanna-Tabor. ${ }^{80}$ Her point is that religious associations are, from the state's perspective, voluntary membership organizations. The exemptions granted to religious non-profits derive from the religious community they serve, not from their secular non-profit corporate status. But she does not tell us what makes religious associations so special as compared with other voluntary membership associations that they merit unique legal treatment. Nor does she worry about the distinction between churches - religious membership entities par excellence - and non-profit organizations owned by them - old age homes, gymnasiums, hospitals, schools, drug treatment centres, universities. The latter are not membership organizations and they too employ and serve many who do not belong to the church with which the entity is affiliated. Instead of questioning the ACA's exemption for non-profit organizations that are not churches, Justice Ginsburg signed on to the reasoning in Hosanna-Tabor. She also apparently concurs with the Court's accommodation in the 1987 Amos case. Supposedly there too 'furtherance of the autonomy of religious organizations often

For a theory of conscience, membership, affiliation and association that might justify certain accommodations see Nelson, 'Conscience, Incorporated.'

76 Hobby Lobby, 573 U.S. at 29 (Ginsburg, J., dissenting).

77 Dewey, 'The Historic Background of Corporate Legal Personality', 666-9.

78 Ibid., 667

79 Hobby Lobby, 573 U.S. at 18 (Ginsburg, J., dissenting).

80 Ibid., 15. 
furthers individual religious freedom as well' ${ }^{81}$ But, both of these cases involved clear harm to others, namely, to the dismissed employees. Given Justice Ginsburg's concern to distinguish between religious non-profits and for-profit business corporations, so as to rebut the Court's opinion in Hobby Lobby, her inattention to the deeper issue regarding the distinction between religious and secular non-profits is perhaps understandable. But for us, this is where the questioning must begin.

The concession theory cannot help us here. Instead, it points away from acknowledging the 'special character of religious/ecclesiastical corporations'. As Dewey notes, the concession theory was 'essentially the product of the rise of the national state, with its centralizing tendencies and its objection to imperia in imperia at a time when religious congregations and organizations of feudal origin (communes and guilds) were rivals of the claim of the national state to complete sovereignty' ${ }^{82}$ The practical motivation of original concession theory and its periodic revivals has always been to deny an independent ground for this-worldly corporate (religious or any other) jurisdiction, privileges or immunities other than state law and to reject claims to unregulated self-governance prerogatives. From the perspective of the liberal democratic civil state, the corporation in its various forms always presented the problem of how to check the tendency of group action to undermine the liberty of the individual or to rival the public purposes and political power of the state. ${ }^{83}$

The allegedly unique quality of religious association is thus not derivable either from the concession theory or from the nexus of contacts approach. It does however seem to go well with the third theory of corporate personality in the literature, the 'real entity theory'. Devised to challenge the concession doctrine, this theory holds that corporations must be seen as groupings that arise independently from the state and yet are real, irreducible to the individuals constituting and composing them. ${ }^{84}$ Corporate personality is sui generis - irreducible to and autonomous from the personhood of the individuals comprising corporate associations - and it deserves state recognition. The corporation endures over time while individuals associated with it change or die; corporations are autonomous, self-sufficient and self-renewing agents with purposes and functions of their own. Accordingly, the real entity theory avoids the dilemma inherent in Justice Alito's nexus of contracts approach in Hobby Lobby, which identifies corporate rights with the rights of their members jeopardizing the distinctiveness of corporate rights not enjoyed by natural persons. By the same token, it construes corpora-

81 Ibid., citing Corporation of Presiding Bishop of Church of Jesus Christ of Latter-day Saints v. Amos, 483 U. S. 327, 342 (1987) (Brennan, J., concurring in judgment).

82 Dewey, 'The Historic Background of Corporate Legal Personality', 666.

83 Ibid., 667 (citing Ernst Freund, 'Historical Jurisprudence in Germany', Political Science Quarterly 5 (1890)).

84 This conception was imported into the US by pro-business theorists. See Horowitz, 'Santa Clara Revisited'. The first US Supreme Court case to use real entity theory was Hale v. Henkel, 201 U.S. 43 (1906). 
tions as agents, persons capable of holding constitutional rights against government, which is hard to argue for on the concession theory. ${ }^{85}$

There is no need to impute a metaphysical doctrine of group spirit to the real entity theory of the corporation. Easy incorporation rules implicitly acknowledge the civil associative impulse while insistence on its 'real' personality could mean that under law, certain legal rights, exemptions and agency are ascribed to the incorporated association rather than to the incorporators. Indeed, over time, important constitutional protections were extended to 'corporate persons' in the US $^{86}$ Nevertheless, the real entity theory does not tell us which constitutional rights should be ascribed to the entity. ${ }^{87}$ While corporations may be legal and constitutional persons for some purposes, they may not be for others. They certainly do not enjoy all the constitutional rights of natural persons. Moreover, the real entity theory cannot tell us why the corporate religious are deemed so special and unique that they merit blanket exemptions from generally valid law and a mode of deference to internal autonomy that no other corporate entity (for-or non-profit) or voluntary association enjoys.

When they impinge directly on the rights of identifiable third parties and harm them, we must rethink the basis of blanket claims to exemption, framed in terms of the autonomy of religious conscience, integralist conceptions of ethical integrity or corporate religious self-governance. Why should religious freedom rights trump rights to non-discrimination on the basis of gender or age, or secure immunity from the jurisdiction of labour law enforcement? ${ }^{88}$ None of the available secular theories of the corporate compel or account for this doctrinal result. ${ }^{89}$ Thus, we must reflect anew on the non-legal conception of the corporate underlying the Court's opinions and what it logically entails regarding jurisdiction as well as justice. ${ }^{90}$ The real entity theory is not invoked in Hobby Lobby or in HosannaTabor. But it is my thesis that a particular political theological version of that theory pertaining to the corporate religious is doing the work regarding the unique deference to church autonomy in Hosanna-Tabor, and to the integralist religious claims of the controlling stockholders in Hobby Lobby.

85 Ron Harris, 'The Transplantation of the Legal Discourse on Corporate Personality Theories: From German Codification to British Political Pluralism and American Big Business', Washington \& Lee Law Review 63(4) (2006): 1421-78 at 1473.

86 Sometimes invoking real entity theory as the justification. See Horwitz, 'Santa Clara Revisited', 175, 222.

87 Nelson, 'Conscience, Incorporated', 1573.

88 NLRB v. Catholic Bishop of Chicago 440 US 490 (1979) denying the National Labor Relations Board jurisdiction to certify unions to collectively bargain for lay teachers of secular subjects in religious schools.

89 See the debate over indeterminacy of corporate concepts between Dewey, 'The Historic Background of Corporate Legal Personality', 669-70 and Horwitz, 'Santa Clara Revisited', 224.

90 See Nelson, 'Conscience, Incorporated', 1573; Dewey, 'The Historic Background of Corporate Legal Personality’. 


\section{Why accommodate religion?}

Recall that the 'accommodation' claims do not contest the constitutionality of a general law, but its applicability to religious groups. What justifies blanket exemptions from valid law? A key player in First Amendment jurisprudence, Michael McConnell, advanced the main arguments some time ago and has been refining them ever since, exerting much influence on the Court and on fellow jurisprudes. ${ }^{91}$ As he notes, accommodation claims turn on the assumption that religion is special and unique. He gives us three reasons. First, there's the special status the First Amendment itself bestows on religion. Though the Constitution does not say exemptions are mandatory or even allowed, McConnell interprets it that way. ${ }^{92}$

Second, religious pluralism and liberty are among the core commitments of a liberal constitutional republic. Indeed, the American polity, he insists, is 'not secular but pluralistic'. ${ }^{93}$ The pluralist model rejects the assumption that the polity is based on secular (i.e.,) relativist Enlightenment values or that secularism is a neutral position. ${ }^{94}$ Moreover, McConnell insists that liberalism itself entails the value of religious plurality and the American Constitution's religion clauses embody the logic of limited government dear to liberalism. ${ }^{95}$ The animating purpose of American pluralist constitutionalism is thus to enable people of all religious persua-

91 McConnell, 'Accommodation of Religion'; see, e.g., Brief for the Petitioner, Hosanna-Tabor, (filed June 2011) (submitted, in part, by Douglas Laycock) (available online at <www.americanbar.org/ content/dam/aba/publishing/previewbriefs/Other_Brief_Updates/10-553_petitioner.authcheck dam.pdf >); Perry Dane, 'The Varieties of Religious Autonomy', in Church Autonomy: A Comparative Survey, ed. Gerhard Robbers (New York: Peter Lang, 2001) (cited by Brief for Amicus Curiae International Center for Law and Religion Studies at Brigham Young University in Support of Petitioner, Hosanna-Tabor, (submitted by Elizabath A. Clark, among others) (available online at <www.americanbar.org/content/dam/aba/publishing/previewbriefs/Other_Brief_Updates/10 -553_petitioneramcuintlcenterforlawandrelstudies.authcheckdam.pdf >)).

92 See McConnell, 'Accommodation of Religion: An Update', 722. See also McConnell, 'The Origins and Historical Understanding of the Free Exercise of Religion', arguing that originally the Free Exercise Clause exempted individuals from civil laws to which they had religious objections if their non compliance was peaceful. For a rebuttal, see Phillip Hamburger, 'A Constitutional Right of Religious Exemption: an Historical Perspective', The George Washington Law Review 60 (1992): 932, arguing that even when Americans believed religious freedom was based on a higher authority than civil government, they did not conclude that this entailed an exemption from civil laws, nor that such exemptions were constitutionally required.

93 McConnell, 'Accommodation of Religion', 14 and Michael W. McConnell, 'Believers as Equal Citizens', in Obligations of Citizenship, ed. Nancy L. Rosenblum (Princeton: Princeton University Press, 2000), 103. In the former he states, '...the nation is understood not as secular but as pluralistic'. But in the latter and later piece it is the American state, not the nation that is to be seen as religiously pluralist rather than secular, a far more contentious idea.

94 McConnell, 'Believers as Equal Citizens', 103-4, eliding the distinction between political and comprehensive secularism. See Rajeev Bhargava, 'Political Secularism', in The Oxford Handbook of Political Theory, eds. John S. Dryzek, Bonnie Honig, and Anne Phillips (Cambridge: Oxford University Press, 2008), 636-53 and Jean L. Cohen, 'Rethinking Political Secularism and the American Model of Constitutional Dualism', in Religion, Secularism and Constitutional Democracy, eds. Jean L. Cohen and Cecile Laborde (New York: Columbia University Press, forthcoming). 
sions to be citizens of the commonwealth with the least possible violence to their religious convictions. If this requires accommodation through relaxation of the general rules of society, it is worth the price. ${ }^{96}$ In the epoch of the regulatory state, religious exemptions from civil law become all the more necessary for the protection of these liberal values. ${ }^{97}$ Since liberalism is a regime of fair procedures, the non-perfectionist liberal state must leave the development of morals and conceptions of the good to citizens' associations. It is not hard to guess which associations he has in mind.

Yet the heart of the matter lies elsewhere for pluralist accommodation-ists. The third reason religion requires unique constitutional treatment is this: '...while unable to establish a national religion, the liberal state also cannot reject in principle the possibility that a religion may be true; and if true, religious claims are of a higher order than anything in statecraft' ${ }^{98}$ In short, religious claims - if true are prior to and of greater dignity than the claims of the state. ${ }^{99}$ To deem the state's authority supreme is to deny the possibility that a transcendent authority could exist. Religious claims are thus special both because the state is constitutionally disabled from disputing their truth and because it cannot categorically deny the authority on which such a claim rests! ${ }^{100}$

To be sure, the epistemic argument regarding government's incompetence to judge the truth of religion does not make the latter unique: the same could be said for scientific truth or for aesthetic judgments, as McConnell himself acknowledges. ${ }^{101}$ Nor does it compel accommodation. McConnell notes that the incompetence of the magistrate regarding religious truth was originally coupled with an individualist premise hailing from Protestantism positing the conscience of the individual as sacrosanct in religious matters, culminating in the constitutional bargain that forbade government from establishing any form of religious orthodoxy. This singles out religion and sets it apart in a way that no other worldview is set apart. ${ }^{102}$ But this does not involve an epistemic claim regarding the autonomy of individual reason. McConnell is quick to note that this apparently individualist argument is premised on a more basic assumption, namely that 'religious freedom was not merely a matter of personal autonomy, but rather, arose from the duty of each individual to worship God in accordance with the dictates

96 McConnell, 'Believers as Equal Citizens', 103.

97 As does funding of religion for fairness reasons, at least according to McConnell. Michael W. McConnell, 'Religion and its Relation to Limited Government', Harvard Journal of Law \& Public Policy 33 (2010): 943-52.

98 McConnell, 'Accommodation of Religion', 15.

99 Ibid., 15 'If there is a God, His authority necessarily transcends the authority of nations; that, in part, is what we mean by God'.

100 The idea of a higher authority and government incompetence regarding religious truth is not restricted to monotheism or 'Western' religions argues Michael W. McConnell, 'The Problem of Singling out Religion', DePaul Law Review 50 (2000): 23.

101 Ibid.

102 Ibid. 
of conscience'. ${ }^{103}$ He draws the conclusion that 'freedom of religion' is thus not a claim of the autonomy of individual conscience, but rather for an allocation of authority between two jurisdictions: the earthly and the divine. Attempts to coerce religion are an 'invasion of God's prerogative'. ${ }^{104}$ It is true that not everyone believes in god, but no matter, belief in the reality of god is not necessary to the argument about the special character of religion. One merely needs to accept conditionally that if there is a god, this idea can be revealed only through the conviction and conscience of the individual and not through the dictates of the state. $^{105}$

There's more. This jurisdictional premise is deemed to be the ground of liberal constitutionalism's commitment to the separation of church and state and to accommodation. Reference to a higher authority explains why religious commitments are unique and why the state must refrain from interfering in the governance, or religious requirements/observance, of religious groups and individuals. In short, 'the principle allegedly underlying the First Amendment is that the freedom to carry out one's duties to God is an inalienable right, not one dependent on the grace of the legislature'. ${ }^{106}$ This applies both to freedom of individual conscience and to institutional Church autonomy. At issue is the unique un-free freedom of the religious who are obligated by another and higher authority to live and practice their community's religious law and duties. 'The essential point is that religious believers have an allegiance to an authority outside the commonwealth' ${ }^{107}$ It is this that leads to 'citizenship ambiguity' (conflicting loyalties) for the religious and demands for accommodation as a requirement of equal citizenship. While he notes that Christianity '...gave men two legislative orders, two rulers, two homelands...and puts them under two contradictory obligations...' he is careful to insist that citizenship ambiguity is not an oddity of Christian doctrine but is present in any religion that recognizes a divine or transcendent normative authority. 108

McConnell is not alone in tying religious freedom, pluralism, and accommodation to a strong jurisdictional sovereignty claim. Steven D. Smith also maintains that the principles of religious freedom, and separation between the religious and the secular, so basic to modern liberal constitutionalism, have their genesis and ground in the old 'two-realm' theory of distinct jurisdictional domains divided between two autonomous corporate entities - Church (pope) and State (king). ${ }^{109}$ The competing sovereignty claims and the inability of religious or secular rulers

103 Ibid.

104 Ibid., 29.

105 Ibid., 30.

106 McConnell, 'Accommodation of Religion: An Update', 692.

107 My emphasis. McConnell, 'Believers as Equal Citizens', 91.

108 Ibid., 92.

109 Smith, The Disenchantment of Secular Discourse, 113, 115. See also Perry Dane, 'The Maps of Sovereignty: A Meditation', Cardozo Law Rev 21 (1991), arguing that sovereign status of religious communities and plural legal jurisdictions is presupposed by the First Amendment religion clauses but that the latter is not the source of religion's sovereignty. 
to wholly dominate the other is what allegedly led to a fruitful legal pluralism, providing the terrain on which the idea of autonomous group rights could emerge. This is also allegedly the main ground of modern constitutionalism and liberal rights. ${ }^{110}$ The latter limit state sovereignty and, hence, protect liberty. While the Protestant Reformation transformed the meaning of 'the church' into the priesthood of all believers, dispensing with the corporate ecclesiastical hierarchy, the church community is still the medium (corps) through which the word of God is preached. There was thus a shift in rather than a break from the idea of freedom of religion. As Smith puts it: 'the medieval commitment...to keeping the church independent of secular jurisdiction, was partially rerouted into a commitment to keeping individual conscience free from secular control'. ${ }^{111}$ Moreover, 'the medieval slogan, 'libertas ecclesiae,' begat the modern 'freedom of conscience". ${ }^{112}$ To be sure, in the aftermath of the religious wars, the Peace of Augsburg and Westphalian treaties, cuius regio eius religio became the new European norm, with monarchs establishing and controlling religion via their claim to absolute sovereignty and jurisdiction within their realm. Nevertheless, toleration was embraced as prudent and later principled state policy, justified by a conception of liberty of conscience that framed religious belief, dogma and ritual as non-cognizable by the state. Liberty of conscience and of 'the church' - now seen as a voluntary association of believers - is thus construed as a 'corporate' sovereignty claim. At stake is a domain under the autonomous dominion of the lord of conscience, Christ, the authoritative source for the obligations and laws orienting religious conscience. Accordingly, Smith maintains that there is both a generative connection and a jurisdictional cast to the liberty of conscience tradition undergirding the US constitution's First Amendment. This tradition, too, apparently entails the idea of the church as a corporate community - a community in Christ, under his rightful sovereign dominion which the state may not invade and over which it has no jurisdiction. ${ }^{113}$

We can now see more clearly just what conception of the corporate religious (and of pluralism) is being resurrected in contemporary legal theory and informing Court jurisprudence. We can also grasp what the real stakes are in the attacks on political/legal secularism. I have claimed that a 'political theological' conception of the corporate community is doing the work in both Court decisions discussed above and that it is the conceptual core of the jurisdictional pluralist accommodation-ist arguments. By invoking the old two realm theory and deriving the idea of freedom of religious conscience (or ethical integrity) from the autonomy of the corporate religious community, today's religious pluralists and the Court in Hosanna-Tabor, are reviving medieval political theological doctrines of the corpo-

110 Ibid., 116. See also Brian Tierney, Religion, Law and the Growth of Constitutional Thought (Cambridge, England: Cambridge University Press, 1982), 1150-650 and Harold J. Berman, Law and Revolution: The Formation of the Western Legal Tradition (Cambridge, Mass: Harvard University Press, 1983).

111 Smith, The Disenchantment of Secular Discourse, 123.

112 Ibid.

113 Ibid. 
ration and of sovereignty first developed in the aftermath of the Papal Revolution of the late eleventh and twelfth centuries. ${ }^{114}$ As is well known, canonists gave the claim of 'libertas ecclesia' a legal basis by adapting the concept of the corporation, (universitas) from Roman law and applying it to the church so as to construe the latter as an autonomous self-governing unified body. But, they did so by theologizing the originally secular, Roman law concept. ${ }^{115}$ Accordingly, church autonomy and prerogatives do not stem, as under Roman law, from a state grant, but from the membership of all Christians in the mystical body (corpus mysticum) of Christ. As a mystical body or person, the corpus/universitas, which is the church, gains its unity, its authority, its jurisdiction (the right to say, make the law) and its governance prerogatives from Christ and God. The pre-existing Christian community of faith and loyalty was construed as a corporate body which for the canonists grounded the separate legal identity of the church under the papacy, the supremacy of the papacy over the entire clergy as well as clerical independence from the secular branch of society. ${ }^{116}$

The idea of the two natures of Christ, one divine and one human, is not new. The former nature is, of course, deemed the eternal 'real body' of Christ in which all Christians partake during the eucharist, distinct from Christ's natural individual body that dies. But the concept of the mystical body of the church as a corporation exercising this-worldly powers over its members (all Christians) was, in the aftermath of the Papal Revolution, premised on a new sociological distinction between an individual and a collective body, the first being Christ himself, the second a (collective) body of which he is the head. ${ }^{117}$ This mystical conception of the church as a corporation, i.e., as a body and unity, was the product of a merger of the Roman law concept of the corporation and the newer Christian idea. ${ }^{118}$ The result was a political theological conception of the corporation that precedes and is autonomous from the state.

The new corporate concept - so useful for asserting governance powers, autonomous legal order, jurisdictional power, and other quasi-state-like features of the very worldly church organization and, ever since the twelfth century Papal Revolution, for exalting the emperor-like qualities of the pope and his sovereignty/ supremacy claims - retained its religious and mystical connotations thanks to the blending of the term 'corpus' into that of 'universitas' ${ }^{119}$ Kantorowtiz's point is to argue that the concept of the corporation as a mystical body was 're-secularized', meaning that the Church is a body politic. That corporate concept was subsequently transferred to any and every collective 'body' in the secular world via the organic philosophies and discourses of the high middle ages and thereafter.

114 See Berman, Law and Revolution, and Ernst Kantorowitz, The King's Two Bodies: A Study in Medieval Political Theology (Princeton: Princeton University Press, 1957).

115 Kantorowitz, The King's Two Bodies, 193-232; Otto Gierke, Associations and Law (Toronto: University of Toronto Press, 1977), 144-51.

116 Berman, Law and Revolution, 51, 95.

117 Kantorowitz, The King's Two Bodies, 198.

118 Ibid., 202. See also Gierke, Associations and Law, 144-53.

119 Kantorowitz, The King's Two Bodies, 206. 
Hence, the body metaphor in western political theory: the conception of the state as a body, i.e., a corporation (corps); of society as a body made up of a hierarchy of lesser bodies or organs; and the application of the corporate body metaphor to every kind of universitas - from the state, to the people, to the king in parliament, to smaller entities such as the city or the guilds. ${ }^{120}$ This political theology of the corporate has its origin here. ${ }^{121}$

As Harold J. Berman points out in his later study of the same period, oft cited by the pluralist accommodation-ists, the Papal Revolution fostered the corporate consciousness of the clergy and supremacy claims over the secular branch of society. ${ }^{122}$ With the help of the canonists and the new political-theological concept of the corporate, legal authority was found to support the latter's claims of autonomy. 'Freedom of the church', i.e., freedom from control by 'the laity' - civil secular power - fostered and stimulated clerical class consciousness and the development of the first trans-local, trans-tribal, trans-feudal, trans-national class in Europe to achieve political and legal unity. ${ }^{123}$ This was, to be sure, also predicated on the very worldly power of the church, which owned between oneforth and one-third of the land in Europe, controlled the production and distribution of 'spiritual' goods as confessors, preachers of sermons, guardians of salvation and whose ecclesiastical courts acquired far reaching jurisdiction over key domains of civil life (performers of marriage, educators in schools) and benefits (exemptions) for the clergy from civil law. ${ }^{124}$ Equally important for the legal pluralists is the fact that the competing supremacy claims of monarchs and Popes were unsuccessful. As Berman, an advocate of legal pluralism and an opponent of 'all encompassing' secularism, argues, the infamous 'investiture' struggles culminated in the agreement that there are and should be two jurisdictions: one under religious authority and the other under secular civil authority, disagreement over the relative scope of each not withstanding. While time was on the side of the expansion of the secular jurisdiction at the expense of the ecclesiastical all over Europe, 'such shifts in the balance of power had to be carried out in the context of legal competition and compromise'. ${ }^{125}$ The lasting and allegedly salutary effect of this on the Western legal tradition was, accordingly, legal pluralism. 'Plural juris-

120 Ibid., 208, 210, 228.

121 For Kantorowitz, political theology can entail the theologization of secular concepts, as in the case of the Roman concept of the corporation construed as a mystical body and the sovereign seen as the sacralized head of that body. It can also involve the politicization of theological concepts, as in the case of the theologized concept of the mystical organic body to describe 'secular' corporations. Kantorowitz, The Kings Two Bodies, 192. The secularization of theological concepts is a third conception used by both Kantorowitz and Schmitt. For the latter, 'political theology' also refers to the homology between metaphysical/religious worldviews and conceptions of political order. See Carl Schmitt, Political Theology: Four Chapters on the Concept of Sovereignty (Cambridge, Mass: MIT Press, 1985), 46.

122 Berman, Law and Revolution, 95 (addressing the sovereignty claims of the Pope).

123 Ibid., 108.

124 Ibid., 109 and 265-9 (for a description of the special powers and privileges of the clergy).

125 Ibid., 268. 
dictions and plural legal systems became a hallmark of Western legality'. ${ }^{126}$ The multiplicity of bodies of law still extant in eighteenth century England in Blackstone's time (ranging from natural and ecclesiastical law to Roman law, common law, statute law) and the myriad courts administering those various kinds of law created the opportunity to appeal from one jurisdiction to another, allegedly enhancing freedom by establishing limits on each power through counter-powers and competing jurisdictions.

Nonetheless, as we know, the story does not end here. Berman notes that " $w]$ hen the church eventually became in the secular mind an association within the state, as contrasted with an association beyond and against the state, then the plural jurisdictions in each country of the West were swallowed up by the one national jurisdiction, and the plural legal systems were absorbed more and more by the one national legal system' ${ }^{127}$ The polemical purpose of this genealogy is, obviously, to tie the decline of church privilege via legal pluralism to the triumph of one comprehensive national secular jurisdiction of the sovereign state and to challenge it as a threat to liberty. Smith shares fully in this assessment. He too laments the triumph of secular jurisdiction (state sovereignty) and equates it with the loss of 'religious liberty' along with the loss of 'depth', meaning, and a convincing foundation for secular legitimacy of the state itself. ${ }^{128}$ Yet there's hope:

There is in most countries of the West not only a residual conflict of jurisdictions...but also a constitutional limitation upon the power of the state to control spiritual values. ... There is still the belief...that if the legal boundaries set by the state conflict with higher law, then there is a right - and a duty - to violate them. ${ }^{129}$

Thus limits on government are interpreted as legal jurisdictional boundaries set by higher law based not on the Constitution or the democratic people's will, but on religious sources.

Revival of the two-world theory, and a reliance on a political theological conception of the corporate and of sovereignty to undergird religious legal pluralism, clearly inform Smith's and McConnell's claims about the basic requirements of liberal constitutionalism and the freedom it aims to guarantee. ${ }^{130}$ Indeed, Smith's point is to demonstrate the jurisdictional cast of the American liberty of conscience and to argue that liberal constitutional commitments predicated on this tradition are at risk due to the secularization of the secular and the monopoly of sovereignty by the modern state. He notes, disapprovingly, that today the secular

129 Berman, Law and Revolution, 269.

130 This challenges the Cambridge School that accords fourteenth-fifteenth century republicanism a central role in the revival of constitutionalism. See, e.g., Quentin Skinner, The Foundations of Modern Political Thought (Cambridge: Cambridge University Press, 1978). 
state is no longer construed as one of God's domains. It is now seen as 'non-religious'; and the entirety of jurisdiction - sovereignty - apparently belongs to it alone. ${ }^{131}$ Instead of a salutary legal pluralism following naturally from the twoworld theory, we get 'monistic, absolutist' state sovereignty with no limits other than those it imposes on itself. Whatever freedoms 'the Church' continues to enjoy, including its status as a corporate entity, are simply seen as concessions from the state. ${ }^{132}$ The commitment to religious liberty is insecure in such a context, in the religious pluralists view, since the principle that anchors it - that religion is a realm under an authority that transcends the secular - becomes noncognizable under modern sovereignty. ${ }^{133}$ Secularism turns jurisdictional issues into matters of justice that the state decides. So monistic state sovereignty puts all our basic freedoms at risk.

The political theological conception of the corporate, of sovereignty and their foundation in the two-world theory allows adherents to claim an autonomous source for religious 'freedom', while enlisting liberal constitutionalism on their side. The project is to challenge the liberal democratic state's supremacy over 'the Church', along with its monopoly of coercive law making. ${ }^{134}$ Accordingly, the autonomy, prerogatives and corporate status of the religious are not derived from the civil law but from a non-civil higher authority. Integralist demands for accommodation based on religious conscience or more broadly, ethical integrity, have the same structure.

It should now be obvious that this challenge is also, au fond, a sovereignty bid. ${ }^{135}$ Indeed, a proliferating strand in the church autonomy and accommodation literature makes this quite explicit. It openly argues that religious exceptional-ism is predicated on the deep structural understanding that religious organizations are and function as sovereigns, i.e., as independent non-state legal orders. ${ }^{136}$ But 'legal pluralism' is not a descriptive claim to the effect that religious norms orient the behaviour of adherents in a 'law like' manner. Rather, the 'religion as sovereigns approach' frames 'religious freedom' as entailing shared or dual sovereignty

131 Smith, Disenchantment of Secular Discourse, 131.

132 Ibid., 134-5.

133 Ibid.

134 Ibid., 123. See also Michael McConnell, 'Accommodation of Religion', and McConnell, 'Accommodation of Religion: An Update'. For an earlier legal pluralist attempt at resurrecting what amounts to neo-medievalism, see Figgis, Churches in the Modern State.

135 There is a burgeoning literature on church autonomy. See the papers presented at the Annual International Law and Religion Symposium of the International Center for Law and Religion Studies, published in Brigham Young University Law Review 2004 (2004).

136 See Smith, Disenchantment of Secular Discourse; Perry Dane, 'The Maps of Sovereignty' and Perry Dane, 'The Corporation Sole and the Encounter of Law and Church', in Sacred Companies, Organizational Aspects of Religion and Religious Aspects of Organizations, eds. Nicholas Jay Deremath III, et al. (New York: Oxford University Press, 1998); Paul Horowitz, 'Churches as First Amendment Institutions: of Sovereignty and Spheres', Harvard Civil Rights and Civil Liberties Review 44 (2009): 79-132 and Clark, 'Religions as Sovereigns'. 
with the state. ${ }^{137}$ Despite the critique of state 'monism', the religious jurisdictional 'pluralists' themselves rely on an absolutist political-theological conception of sovereignty - as command located in a power that is legibus solutus. Religions understood as authoritative communities rather than as belief systems, and religious authority as derived from a divine or transcendent source of normative order acknowledged by its 'citizens', is the basis for asserting that they are the archetypical non-state legal sovereigns. ${ }^{138}$ Two demands flow from this 'understanding' first, for the partial de-territorialization of sovereignty with respect to religious organizations; second, for recognition of the sovereignty of religious nonstate legal orders by the state, and the demand that they are treated with the dignity due another sovereign! ${ }^{139}$ Elizabeth A. Clark cites Hosanna-Tabor's deference to the autonomous internal governance of the church as an indication that US law is bound up with the jurisdictional understanding of religious freedom entailing supreme control or sovereignty by the religious in core domains. ${ }^{140}$ Indeed, she invokes the US experience of 'shared sovereignty' in federalism as a heuristic for understanding what is at stake. The federalist analogy is meant to justify the idea of shared sovereignty with religions as the quintessential non-territorial, non-state, transnational, corporate sovereign legal order. The 'religionas-sovereign' theory accounts for the uniqueness of claims for church autonomy, and integralist demands for accommodation of individuals' needs for ethical integrity (Hobby Lobby). It frames accommodation of religious freedom as a question of inter-sovereign respect. ${ }^{141}$ From this perspective, religious autonomy is more than a right of free exercise: it requires that one legal order recognize the prerogatives of another as a legitimate occupant of sovereign space. ${ }^{142}$

All of the jurisdictional accommodation-ists, church autonomists and religion-as sovereignty-theorists are thus legal pluralists who reject 'monistic' state sovereignty. Their gambit however is not only to insist that the religious are unique among non-state associations and communities, thereby meriting special accommodations from public law. The broader project is to challenge the 'secularist' conception of the modern state with its monopoly of sovereign coercive law making. Re-assertion of autonomous jurisdiction frames the corporate religious as an autonomous governance domain immune to state regulation while throwing down the gauntlet to the modern liberal democratic conception of the civil state. This is the deeper meaning of the otherwise rather baffling claim noted above, that the modern liberal democratic constitutional state is not secular but 'pluralist'.

137 Jean L. Cohen, 'The Politics and Risks of the New Legal Pluralism in the Domain of Intimacy', International Journal of Constitutional Law 10 (2012): 380-97 (on the different forms of 'legal' pluralism).

138 Clarke, 'Religions as Sovereigns', 7.

139 Ibid., 7.

140 Ibid., 8.

141 Ibid., 12. See Dane, 'The Maps of Sovereignty'.

142 Ibid., 966. 


\section{The pluralist critique of state sovereignty, again}

If criticism of monistic, omni-competent state sovereignty in the name of plurality and liberty sounds familiar, that's because it revives early twentieth century pluralist arguments, especially those of John Figgis and Harold Laski. ${ }^{143}$ Drawing on Gierke's history of associations, turn-of-the-century British (and French) pluralist theorists reached back to the medieval corporations - the town, the university, the guild, the church - to show that these were neither derived from the state nor reducible to an aggregate of privatized individuals - their point being to challenge both statism and market individualism. ${ }^{144}$ They attacked 'monistic' state sovereignty by insisting on the autonomous, sui generis, real nature of corporate group life and group personality. Gierke's 'real entity' theory of the corporation was adapted into a wholesale assault on the prevailing concession theory tied to the absolutist conception of state sovereignty and expanded into alternative, 'pluralist' conceptions of the state itself. ${ }^{145}$ By insisting on the spontaneous, nature of corporate group life generated through the natural voluntary association and solidarity of members, pluralists could argue that civil associations must be permitted and their autonomy acknowledged by the state. ${ }^{146}$

Figgis' target was British Erastianism - state establishment and instrumentalization of the Anglican Church, but he insisted that disestablishment was insufficient to secure religious freedom. He knew well that disestablishment did not end the regulation of churches. ${ }^{147}$ That, he maintained, requires recognition of churches' autonomous rule-making power and 'corporate dignity'. While he does argue that all natural associations have a life of their own, Figgis singles out the

143 On the British pluralist school see Paul Q. Hirst (ed.), The Pluralist Theory of the State (New York: Routledge, 1989).

144 Gierke, Associations and Law; see Cecile Laborde, Pluralist Thought and the State in Britain and France 1900-1925 (London: Macmillan Press, 2000), especially Chapters 2 and 4, on French anarchist pluralists and corporatist legal pluralists. See also Barkan, Corporate Sovereignty, 81-85 and Harris, 'The Transplantation of the Legal discourse on Corporate Personality'.

145 While their conceptions of the pluralist state differed, ranging from an organic coordination scheme (Figgis), to a functionalist contractual integration scheme (Laski and Cole), to more corporatist models (Duguit), their critiques of the monistic state and of state sovereignty were quite similar as was their insistence on the spontaneous autonomous nature of group life. See Hirst (ed.), The Pluralist Theory of the State, and Laborde, Pluralist Thought and the State in Britain and France, 46-47.

146 Figgis, Churches in the Modern State, 41-42. For the socialist pluralists, the emphasis was on solidarity in workers associations but for Figgis, with his Anglican-catholic bent, it was on an organic traditional conception of community.

$147 \mathrm{Ibid}$. Disestablishment in the US did not end state regulation of religion. Indeed easy access to corporate status through general incorporation came with state regulation. General incorporation statutes in the various American states assumed that churches would be congregationally structured, with the laity exercising firm control over the clergy and economic activity limited to generating sufficient income to pay a pastor and maintain a meetinghouse. So-called mortmain provisions sharply limited how much property a church could own, the purposes for which it could be used, and the methods by which it was to be controlled and state laws stipulated requirements regarding internal governance. Gordon, 'The Place of the Faith'. 
church and religious society as special and unique. ${ }^{148}$ Conceding that churches in the modern world must be construed as voluntary associations, they are distinctive in that they are 'true' organic communities shaping and embracing the whole of an individual's life in which authority over members is crucial to the meaning of the religious community. ${ }^{149}$ The Church exists by an inward living force with powers of self-development like a person. Therefore, its real corporate unity and internal constitutional authority should be accepted by the state with no further questions asked. ${ }^{150}$ The notion that corporate religious existence is a mere concession from the state, for Figgis, is a notion that 'no religious society can admit without being false to the very idea of its existence or placing the Divine Law at the mercy of political convenience'. ${ }^{151}$ In short, Figgis resurrects the political theological conception of the corporate community regarding churches. For our contemporary jurisdictional religious pluralists, Figgis is thus the most important modern precursor.

Laski's concerns differed from Figgis' in that he sought to end restrictions on workers' organizations and opposed the growing regulatory power of the (capitalist) state. He (and other socialist pluralists) embraced the real entity theory to justify the autonomy of civil society associations, especially trades unions, and to serve as the theoretical building blocks of alternative socialist pluralist models of the polity. ${ }^{152}$ This did not involve a mystical conception of community or a political theological conception of the corporate. What the socialist pluralists did share with Figgis, however, was the critique of the doctrine of 'monistic' sovereignty.

The concept of sovereignty at issue here was the absolutist one that posits a single, indivisible hierarchical locus of power and source of law, incapable of legal limitation, located in a single organ, and the non-existence of all other juris-generative bodies. ${ }^{153}$ Whether this organ is the King in parliament (Britain) or a national assembly (France), it is deemed equally levelling and destructive of the autonomy and rights of other social unions. In either case: 'all and every right is the creation of the one and indivisible sovereign... No prescription, no conscience, no corporate life can be pleaded against its authority, which is without legal limitation...To talk of rights against it is to talk nonsense'. ${ }^{154}$ On the monistic conception of sovereignty, the state is the entity that is inherently entitled to

148 Figgis, Churches in the Modern State, 47-48 arguing the sui generis origin of family, churches, clubs, trade unions. It was not until 1919 that he acknowledged the ethical value of trade unions due to their principle of solidarity (brotherhood).

149 On the special Christian mystical conception of organic corporate community. See Gierke, Associations and Law, 145.

150 Figgis, Churches in the Modern State, 36, 40.

151 Ibid., 37, 43 (emphasis added).

152 For a critique of the pluralist conceptions of the state, see Carl Schmitt, "The Ethic of State and the Pluralistic State', in The Challenge of Carl Schmitt, ed. Chantal Mouffe (London: Verso, 1999), 195.

153 Harold Laski, 'The Pluralist State', in The Pluralist Theory of the State, ed. Hirst, 187-8.

154 Figgis, Churches in the Modern State, 85. 
primacy over any other association - precisely the contention the pluralists deny. ${ }^{155}$

The pluralist critics ascribed this conception of sovereignty, in part, to a dogmatism of analytical jurisprudence's theoretical need to posit a final hierarchical source of law so as to assert the unity of the state's legal order. ${ }^{156}$ They note that the 'monistic' conception of state sovereignty derives from absolute monarchy, and the work of Hobbes and Bodin justifying its centralizing, hierarchical thrust against autonomous secular and religious corporate counter-powers. But they argue that this conception was simply transferred from the king to the people with the theories of popular sovereignty and representative democracy. Popular sovereignty legitimizes the laws passed by the democratically elected representative assembly as the sole organ embodying the people's will and the source of the only valid positive law. The democratic political organ, as was its absolutist predecessor, the monarch, is deemed to be legibus solutus, and incompatible with autonomous intermediary group life and counter-powers, leaving nothing between the individual and the state. Accordingly, democratic sovereignty retains the absolutist monistic idea of a centralized hierarchical state with a plenitude of sovereign power, perforce deeming all civil associations as its own creations (via concession) or as threats to its existence. ${ }^{157}$

To the pluralists, (then and now) freedom of the church (Figgis) and indeed all our civil freedoms (Laski) depend on rejecting the dogma of the sovereign state. They try to turn the tables on the concession theory of the corporation by insisting on the real un-derived group personality and corporate life of associations and by insisting that the state's sovereignty and monopoly of law making is itself a legal fiction. ${ }^{158}$ The alternative pluralist conceptions of the polity varied but they all agreed that political and legal pluralism, not state sovereignty, is the appropriate frame for securing freedom to churches and to associated individuals generally. ${ }^{159}$ For the guild socialists, and Laski, the pluralist vision of the state entailed a project of democratization on functionalist grounds in which internally democratic societal corporate bodies in industry and on the level of local government would constitute a federative structure. ${ }^{160}$ The state is just one association among many with no claim to supremacy. Figgis' anti-statist impulses restricted the 'pluralist' state to registering the personality of corporate societies, regulating and coordinating the relations of corporate persons to one another and to natural persons. ${ }^{161}$ While he argues that it is the organic communities rather than majoritarian democracy or individual rights that preserve individuality and real freedom, this is not his main interest: 'Yet our concern...is not with the individual but

155 Harold Laski, 'Law and the State', in The Pluralist Theory of the State, ed. Hirst, 214.

156 Ibid., 197-8; Figgis, Churches in the Modern State, 83-84.

157 Paul Q. Hirst, 'Introduction', in The Pluralist Theory of the State, ed. Hirst, 2.

158 Laski, 'The Pluralist State', 185, 188.

159 Laborde, Pluralist Thought.

160 Harold Laski, 'The Problem of Administrative Areas', in The Pluralist Theory of the State, ed. Hirst, 131-63.

161 Figgis, Churches in the Modern State, 41-42. 
rather with corporate liberty'. ${ }^{162}$ The main point is to negate the state as sovereign, to deny its ethical claim to highest obligation of citizens, and thus to relativize it vis-à-vis other, primarily religious, associations. ${ }^{163}$ Unlike the socialist pluralists, however, religious pluralists from Figgis to our day rely on the absolutist conception of sovereignty to ground the unique prerogatives of religious communities.

Moreover, as Carl Schmitt argued at the time, despite superficial alliances, the advocates of religious and labour associations instrumentalized one another to serve their competing projects. ${ }^{164}$ Indeed, despite their pluralist stance, both entailed a secret monism of their own, pitting universalistic pretensions of international labour against the universalism of the Church. ${ }^{165}$ Certainly with regard to the latter, Schmitt is right to note that, '[t]he Roman Catholic Church is no pluralistic construction'. ${ }^{166}$ As he correctly points out, it is inconceivable for the Catholic Church to permit itself to be treated on an equal level with an international labour union. ${ }^{167}$ Indeed for Figgis, an Anglican Catholic, the Church has its own independent constituent and constitutional authority - a divine sovereign source that no other association can claim. ${ }^{168}$

Interestingly, neither their sovereignty critique nor the Europeans' pluralist conceptions of the state resonated in the US in their own day. ${ }^{169}$ The absolutist conception of state sovereignty targeted by the European pluralists hardly fit the American context of federalism, checks and balances, separation of powers and judicial review and flourishing associational life. ${ }^{170}$ Churches (unlike business enterprises) had enjoyed corporate status through general incorporation laws for nearly a century, and disestablishment occurred in all of the states by the 1830 s. ${ }^{171}$ The resurrection of the sovereignty critique and jurisdictional discourse of church autonomy today is thus all the more striking and its successes, in Court, astonishing. ${ }^{172}$ Presuming that the 'secularist' worldview can't grasp or justify our deepest commitments to liberty, the accommodation-ist project is, allegedly, to restore the 'traditional understanding' of liberal constitutionalism. Recall the

162 Ibid., 58.

163 See Schmitt, 'Ethic of the State and Pluralistic State', 187-8.

164 Carl Schmitt, The Concept of the Political, trans. George Schwab (Chicago: University of Chicago Press, 2007), 41-42, n. 17 (claiming that for Laski the Church serves as a stalking horse for the labor unions. The reverse is also clearly true for Figgis).

165 Ibid.

166 Schmitt, 'Ethic of the State and Pluralistic State', 200.

167 Schmitt, The Concept of the Political, 42.

168 Figgis, Churches in the Modern State, 40.

169 Despite the fact that Laski taught at Harvard from 1916 to 1920 and was the first scholar to offer a pluralist reading of the Tenth Federalist Paper.

170 Harris, 'The Transplantation of Legal Discourse on Corporate Personality Theories', 1443. Laski makes this point in 'The Pluralist State', 185, 198. An American 'pluralist' theory of the state did emerge at the time through the work of Bentley but that was a theory of interest group politics, expanded later into a full blown analytical approach to American government.

171 Gordon, 'The Place of the Faith'.

172 See the work of Dane, Smith, McConnell, Horwitz, Laycock, etc., cited herein. 
genealogy in Hosanna-Tabor framing religious freedom in terms of the early modern jurisdictional battles between church and state. 'The church', the dominant trope in Chief Justice Robert's opinion, is a corporate body, autonomous vis-à-vis secular government, and apparently entitled to immunities from public law. To be sure, 'church' denotes any organized religious community: in a pluralistic religious environment, it references the many, not the one. But a political theological conception of the corporate is operative here, for churches allegedly enjoy these privileges whether or not they are incorporated via a civil law procedure. The deep structure of this sort of accommodation is not a matter of self-limitation of government but of deference to another sovereign's jurisdiction.

\section{Counter arguments: democratic sovereignty and liberal constitutionalism revisited}

Here I can only respond to the two core theses of the jurisdictional accommodation-ists: first, that democratic sovereignty is perforce monistic, absolutist, hierarchical, and levelling of plurality, the antidote being autonomous jurisdictions for religious nomos communities; second, that religious freedom understood in jurisdictional terms is the first, and paradigmatic, liberty in the tradition of liberal constitutionalism, and the basis of the First Amendment religion clauses. I argue that these caricature democratic sovereignty, mis-describe liberal rights and constitutionalism and involve a form of status-group legal pluralism that threatens both.

\subsection{Democratic sovereignty}

The concept of state sovereignty involves a dual claim of internal supremacy (of civil authority and jurisdiction) and external autonomy - self-determination of the domestic constitutional order and political regime. The absolutist conception revived and criticized by today's religious legal pluralists locates unified sovereign powers in a single state organ - a monarch or parliament - and traces the unity of a legal (and political) system back to the legally illimitable will of an uncommanded commander. Democratic sovereignty, on this model, deems the elected legislative assembly to be the sole embodiment of the will of the sovereign people, endowed with all the prerogatives of rule.

This conception of democratic sovereignty is based on a series of confusions: of organ with state sovereignty, of law with command, and of democratic constituent power and popular sovereignty with a political theological corporate model of the people, embodied in a 'representative' ruler. The pluralist critique throws out the baby (the sovereign democratic constitutional state) with the bath water (organ sovereignty). Pace old and new jurisdictional pluralists, however, the absolutist conception is not presupposed by the liberal democratic constitutional state or by an appropriate understanding of popular sovereignty. It was an anachronism ever since the first modern constitutional republic emerged in the US based on the separation of powers, checks and balances, representative government, constitutionalism, the rule of law and popular sovereignty as a principle of legiti- 
macy - not to mention the division of powers entailed by federalism. Constitutional democracy limits arbitrary rule by placing all state organs under civil law and denying sovereignty to any one of them. State sovereignty is a legal concept that pertains to the constitutional legal order in toto. ${ }^{173}$ External sovereignty is not an artefact of illimitable legal or political power. Rather, it is the result of mutual recognition within an international legal and political order that ascribes sovereignty to states based on agreed upon criteria and delimits what prerogatives (law making), rights and duties this entails. In a domestic democracy, internal sovereignty is imputed not to government but to the people, not as an instance that actually rules, not as an organ of the state, but as the sole source of the (in principle revisable) constitutional order.

The legal system and the domestic jurisdiction of the democratic constitutional state must be public, civil, comprehensive and unified. But liberal democratic constitutionalism is predicated on the separation of powers and the rule of law. As the example of constitutional democracies characterized by the division and separation of powers and the increasing internal importance of international law show, this does not rule out division of competences among different organs and loci of public power. ${ }^{174}$ While organ sovereignty is one possibility in democratic republics, it is not the only one and today most constitutional democracies have some form of juridical review. ${ }^{175}$ Even those polities that institutionalize parliamentary sovereignty have mechanisms of accountability and constitutional conventions that limit the legislative organ. ${ }^{176}$ The markers or prerogatives of sovereignty can be divided, normed, placed under law, and delegated amongst public state organs without undermining unity of the state or its legal system.

The early twentieth century pluralist attack on democratic state sovereignty targeted residues of the old 'absolutist' states of the seventeenth and eighteenth centuries for polemical purposes. ${ }^{177}$ The conception they theorized however, was a political theological one, in the sense of a transfer of the attributes once ascribed to God the sovereign - omnipotence, omni-competence, illimitable will, a legibus solutus source of law above the law, etc. - to the secular head of state, the monarch and later to the legislative organ. But this political theological conception of sovereignty (based on a structural homology of ideas of monarchy and monotheism) was a caricature by the late nineteenth century. ${ }^{178}$ Indeed, the formulae of the 'omnipotence of the sovereign' and of the 'absolutist monism' of the

173 Jean L. Cohen, Globalization and Sovereignty (Cambridge: Cambridge University Press, 2012), 21-41, discussing alternatives to the absolutist model of sovereignty.

174 Ibid., 1-41.

175 H.L.A Hart, in The Concept of Law (London: Oxford University Press, 1997), argued this position against organ sovereigntists such as John Austin. Carré de Malberg, in Contribution à la Théorie Générale de l'Etat (Paris: Libraire de la Société du recoil siry, 1920), did so against the French organ sovereigntists.

176 A.V. Dicey, Introduction to the Study of Law and the Constitution (New York: MacMillan and Co., 1889).

177 Schmitt, 'Ethic of State and Pluralistic State', 202.

178 Schmitt, Political Theology, 36ff. 
sovereign political unity destroying all other social groups, were always exaggerations invented originally in the context of the state's quest to prevail against the pluralistic chaos of churches and estates between the sixteenth and eighteenth centuries. As Carl Schmitt correctly noted: 'One makes the task too easy when one sticks to such modes of expression. Even the absolute prince...was forced to respect divine and natural law...the unity of the state has always been a unity of social multiplicity'. ${ }^{179}$ The success of princely absolutism against the 'Ständestaat' (the hierarchical society of corporate orders and mixed government) in monopolizing sovereignty did not end social multiplicity but rather transformed its nature by neutralizing and relativizing the autonomous political power bases and privileges of the estates and churches, opening the path for them to become civil voluntary associations and for democratic constitutionalism to develop.

I submit that the attacks by today's jurisdictional religious pluralists on 'monistic', 'absolutist' democratic sovereignty targets liberal secular constitutional democracy with a clear polemical purpose: to relativize the state and to justify what amounts to a jurisdictional power grab for organized religion. But the critique misses the mark. For internal sovereignty in a constitutional democracy is not ascribed to governmental organs, but to the people who are, qua constituent power, the ultimate source of all publicly legitimate exercises of coercive power. The constitution as higher law regulates ordinary legislation, allocates governmental competences and references the citizenry, the demos, as the ultimate source of its legitimacy. The authority of that law is immanent, not meta-social, deriving from convincing claims to instantiate justice that involve appropriate modes of justification to those affected. ${ }^{180}$ Democratic legitimacy and constitutional democracy do not rest on the two-world theory or on meta-social political-theological guarantees. Indeed, it is incompatible with any transcendent source of binding law or law making authority: democracy cannot 'acknowledge' or 'recognize' the this-worldly jurisdiction of any other sovereign than the people. My point is that the religious legal pluralists' sovereignty critique elides the distinction crucial to a liberal democratic republic between constituted and constituent power, and between the immanent and the meta-social authority. In the case of the absolute monarch, these were fused: legitimacy, authority, and all power were (ideally) located in one person and his sovereignty was ultimately understood and justified in political theological terms. But in a constitutional democracy this is not so. The constituent power is not locatable, the people are not one but many, and they are difficult to identify. Insofar as the idea of popular sovereignty refers to the constituent power it pertains to the practice of co-instituting and establishing the constitution and form of polity by those who are its subjects and citizens. ${ }^{181}$ Insofar as

179 Schmitt, 'Ethic of State and Pluralist State', 201. I do not share Schmitt's new political theology of sovereignty based on the miracle and on the theory of sovereign dictatorship.

180 Rainer Forst, 'The Justification of Human Rights and the Basic Right to Justification: a Reflexive Approach', Ethics 120(4) (2010): 711-40.

181 Andrew Arato, 'Forms of Constitution Making and Theories of Democracy', Cardozo Law Review 17 (1995): 202-254; Andreas Kalyvas, 'Popular Sovereignty, the Constituent Power, and Democracy', Constellations 12(2) (2005): 223-44. 
democratic sovereignty pertains to constituted powers, it refers to the equal rights to vote, stand for office and alternation of office holders, and thus to hold representatives accountable. Democracy entails multiple avenues of participation by the citizenry through their autonomous civil and political associations, publics, movements, parties, and councils. But 'the people' do not rule directly, they are not a body (unlike a monarch), and are not embodied by any particular group, institutional or personal representative. Constitutional democracy entails unity and multiplicity: it separates governmental powers, secures basic liberties, and differentiates between and among the people and organs of government, while guaranteeing the unity of the legal system. It also ensures that all coercive power is under public law and that includes sovereignty itself. But there is no need to construe the constituent power, the 'sovereign' people, or democratic constitutionalism as entailing an embodiment model of the polity, organ sovereignty, or an anti-pluralist autocratic levelling stance towards civil society associations.

Indeed, democracy in principle breaks with the political theology of sovereignty because it does not rest on a theologized corporate conception of the polity, of civil society, or of civil associations. The old organic political theological models of social and political unity required a mediator - an instance that embodies - unifies, holds together - the parts of the 'body politic' through incarnation in an organ that re-presents this unity to society and mediates between the transcendent source of fundamental law and legitimacy and man-made worldly laws, powers, etc. As Claude Lefort argued, the old theologico-political matrix gave the prince sovereign power and made him both a secular agency and a representative of God, the mediator between mortals and the transcendent agencies. ${ }^{182}$ The understanding of the king's body, of the body politic and indeed of all social bodies as mystical bodies corporate meant that the king incarnated in his sacred mystical body the organic community of the kingdom. The monarch condensed within his body, mortal and immortal, the principle that generated the order of the kingdom, itself represented as a body such that the hierarchy of its members, the distinction between ranks and orders seemed to rest on an unconditional basis. ${ }^{183}$

But the deepest philosophical meaning of democracy according to Lefort is precisely that it breaks with this symbolic order, with the political theological corporate organic conception of society and state, and with the embodiment model of sovereignty. For him, democracy

...signifies a phenomenon of disincorporation of power and disincorporation of right, which accompanies the disappearance of the king's body in which

182 Claude Lefort, 'The Image of the Body in Totalitarianism', in The Political Forms of Modern Society (Cambridge, Mass.: MIT Press, 1986), 302 (citing Kantorowitz, The Kings Two Bodies).

183 Claude Lefort, 'The Question of Democracy', in Democracy and Political Theory (Minneapolis: University of Minnesota Press, 1988), 16-17. See also 'The Permanence of the Theologico Politico?', in ibid., 213-55. 
the community was embodied and justice mediated; and, by the same token it signifies a phenomenon of disincorporation of society. ${ }^{184}$

Society, in short, can no longer be represented as a body or as a multiplicity of mystical corporate bodies. Indeed,

[t]he modern democratic revolution...burst out when the body of the king was destroyed, when the body politic was decapitated and when at the same time the corporeality of society was dissolved...The modern democratic revolution is best recognized in this mutation: there is no power linked to a body. Power now appears as an empty place and those who exercise it are mere mortals...Democracy inaugurates the experience of an ungraspable, uncontrollable society in which the people will be said to be sovereign, of course, but whose identity will constantly be open to question.... ${ }^{185}$

Far from levelling social plurality, a democratic constitutionalist sovereign republic is the condition of possibility of a dis-incorporated, diverse and autonomous civil society and associational freedom. ${ }^{186}$

Thus, the jurisdictional pluralist conception of society as multiplicity of religious bodies corporate whose juris-generative capacities, governance prerogatives, and autonomy grounded in a transcendent meta-social authority the state must recognize and refrain from regulating is deeply anti-democratic. The jurisdictional pluralists refuse, unsurprisingly, to apply their corporate metaphor to the secular sovereign state. But they resurrect the political theological conception of the corporate and of sovereign authority for religious communities. Their point is to challenge the right of the civil democratic state to regulate the self-regulation of corporate religious groups. However, the political theological conception of democratic sovereignty is only one possible model and it is au fond anti-democratic. ${ }^{187}$

Justification by public officials of accommodation in a democratic polity cannot invoke a transcendent meta-social source without violating the principles of democratic legitimacy. Nor can we understand the limits erected by constitutionalism to the scope of governmental power as an acknowledgment of some ultimate authority behind the constitution that is other than the constituent power of the people. The two-world theory is not the basis of liberal constitutionalism, nor the ground for the First Amendment religion clauses, or of the separation church and state. To view constitutional guarantees of religious freedom in this way is to desecularize the civil state at its deepest foundations. If such a project were to succeed, it would take us out of the continent of constitutional democracy and into

184 Claude Lefort, 'Politics and Human Rights', in The Political Forms of Modern Society (Cambridge, Mass: MIT Press, 1986), 255.

185 Lefort, 'The Image of the Body and Totalitarianism', 303.

186 Lefort, 'Politics and Human Rights', 249-57; and Jean L. Cohen and Andrew Arato, Civil Society and Political Theory (Cambridge, Mass: MIT Press, 1992).

187 Andrew Arato, 'Political Theology and Populism', Social Research 80(1) (2013): 143-72. 
the terrain of religious status based legal pluralism and, potentially, constitutional theocracy. ${ }^{188}$

This is surely the goal of the burgeoning religion-as-sovereigns literature. Hence the attempt to analogize religious legal pluralism with federalism, insofar as both apparently involve 'sharing' or dividing sovereignty into 'spheres', guaranteeing plurality and freedom. ${ }^{189}$ Elsewhere I have argued against this analogy because it elides the distinction between the division of constitutionally articulated and regulated public institutional and democratically legitimated powers characteristic of modern democratic federalism and the private hierarchies entailed in typically non-democratic and publicly unaccountable religious status group based legal pluralism. ${ }^{190}$ Whether we have in mind US-style territorial federalism or federalisms of multinational states, the self-governing units are in principle democratically structured and involve the local exercise of public power under public law, not a hybrid of private and public powers under divine law. In short, in a democratic federation, the units are in principle congruent in political form to the constitutional democracy at the national level. Some religious groups see themselves as integralist nomos communities, seeking to live the whole of their lives under religious law and to structure all the institutions in which they are involved accordingly. But the democratic constitutional state cannot ascribe them jurisdiction or sovereignty or defer to their groups demands for ethical integrity when the basic rights of vulnerable members or employees are at stake.

\subsection{On liberal rights and plurality}

The religionists portray religious freedom as the most fundamental and paradigmatic liberal liberty without which the edifice of liberal rights limiting the state would rest on quicksand. Yet they also insist that religious freedom is a unique right involving more than negative liberty. It is pivotal yet distinct because its legitimacy allegedly does not derive from the constitution or from the demos but from another authority whose jurisdiction (sovereignty) the constitutional guarantee allegedly acknowledges. Freedom of religion is thus no ordinary liberal right: it construed as a corporate immunity involving privileges - associated with jurisdictional autonomy - such as the right to identify (make) higher law and to obey it, even when it conflicts with civil law, and to be presumptively exempt from civil laws impinging on religion. This is the logic behind 'church autonomy' invoked in Hosanna-Tabor and Hobby Lobby's contradictory ascription of religious freedom for a corporate person created through ordinary business law, yet to which the religious convictions of its owners are ostensibly transferred.

This logic also underpins the claim that religious freedom can't be adequately protected through the liberal rights of association, expression, belief, speech, assem-

188 Ran Hirschl, Constitutional Theocracy (Cambridge, Mass: Harvard University Press, 2010).

189 Clark, 'Religions as Sovereigns', 18-22; Horwitz, 'Churches as First Amendment Institutions'; Dane, 'The Maps of Sovereignty'.

190 Cohen, Globalization and Sovereignty, 39-40. 
bly, privacy, and contract. ${ }^{191}$ Religious liberty, be it an individual right of conscience, ethical integrity or a collective right of self governance, is not grounded, on this view, in the basic system of rights intrinsic to republican constitutionalism, nor on the democratic idea that constitutional rights are the rights we give ourselves, nor in the right to justification we as liberals ascribe to every individual. Rather, the reverse is asserted. Higher meta-social sources of law and an authority other than the demos is deemed the basis of religious liberty, of the separation of church and state, and of the limits on the state that liberalism itself entails. Religious freedom thus requires a distinct and unique constitutional acknowledgment.

I beg to differ. Liberal constitutional democracy is committed to respecting individuals as equal and free persons, to designing legal and political institutions whose first virtue is justice, and hence to a fair distribution of the burdens and benefits of society. Civil interests of peace, security, welfare, equal liberty, and voice in determining matters of justice are the core concerns of a liberal democratic polity. Associational plurality and the system of rights entailed in liberal democratic constitutionalism and modern civil society are, it is true, not concessions of the state. Liberal and democratic theory construes them as matters of justice and as co-constitutive with popular sovereignty, and of democratic constitutionalism. But it does not ground them in an otherworldly source. Liberal rights and democratic constitutionalism presuppose a common civil law that treats people as equals, a rule of law that limits arbitrariness, and a diverse civil society that is no longer representable as a body yet is irreducible to an agglomeration of atomized individuals. This involves a shift from Ständestaat's fragmented yet hierarchical organic society of corporate orders to the modern sovereign state with a new type of constitutionalism. It is a constitutionalism that makes rights a matter of justice, not jurisdiction or privilege. Such rights are complemented by a dis-incorporated unbound civil society populated by new forms of societal plurality: voluntary association, civil publics, social movements and networks. Political theological corporate metaphors are inapt both for civil society and for the liberal state. They may fit the self-understanding of legal sources in constitutional theocracies, but not that of constitutional democracy. ${ }^{192}$

Whatever their historical genesis, neither religious freedom, nor the separation of church and state, nor the idea of a civil polity, nor justifiable legislative accommodations, need rest on the Christian two-worlds theory. If traces of it underpin some laws or court decisions, these anachronisms should be dropped. The US Constitution's religion clauses can be justified qua respect for individual citizens' expressive and associational freedom, equal concern for everyone's ethical integrity, and the protection of religious minorities from discrimination, coercion, and/or status inequality. Equal religious liberty, like other civil liberties, presupposes political secularism, not Christendom, and thus the shape of separation and

191 But see James W. Nickel's interesting counter-argument in 'Who Needs Freedom of Religion?', University of Colorado Law Review 76 (2005): 941-64.

192 Hirschl, Constitutional Theocracy. 
the mode of regulation is a matter of democratic constitutional law and public policy, fully within the remit of the only sovereign recognized by the Constitution, the people, to be determined through their representatives. ${ }^{193}$ The religion clauses of the US Constitution did not resurrect pre-modern political theological concepts of the religious corporation. Nor did the Constitution install religious status-group legal pluralism when it rejected the British models of establishment and organ sovereignty. The religion clauses emerged in response to experiences of discrimination against religious minorities, state establishments that instrumentalized religion for power political purposes and religious factional competition for public monies and power that threatened to subvert the civil character of politically secular republican institutions.

As Justice Frankfurter put it:

...the constitutional protection of religious freedom terminated disabilities, it did not create new privileges. It gave religious equality, not civil immunity. Its essence is freedom from conformity to religious dogma, not freedom from conformity to law because of religious dogma. ${ }^{194}$

Separation that goes with non-establishment in the US or elsewhere does not presuppose recognition of another sovereign, some unique form of Church or religious individuals' autonomy. Nor does it preclude the regulation of self-regulating religious associations so they comport with criminal, civil, constitutional law, and the requirements of liberal justice.

Despite accommodation-ists' efforts to enlist liberalism to their side, the jurisdictional interpretation of religious autonomy is antithetical to liberal constitutionalism. Why? Its core principle is group autonomy, not individual freedom or equality. It challenges the jurisdiction of constitutional and civil rights law when the rights of members or employees of religious communities are at issue. Invocation of the First Amendment to justify their claims for blanket accommodation is disingenuous because the constitutional guarantee is not seen as the legal source of religious freedom as per a liberal interpretation. Instead, it is construed as acknowledgement of another legal order and legitimate occupant of sovereign space. The religionists mean it when they say that, '...religious autonomy is more than a right of free exercise. ${ }^{195}$ Indeed it is not a liberal right at all, but rather an existential sovereignty claim referencing transcendent higher authority that ultimately undergirds religious freedom.

As we have seen, what is at issue is far more than the right of religious corporations to discriminate on the basis of religion in relation to their religious activities in

193 Bhargava, 'Political Secularism' and Cohen, 'Rethinking Political Secularism and the American Model of Constitutional Dualism'.

194 West Virginia Board of Education v Barnette 319 U.S.624,653 (1943) (J. Felix Frankfurter).

195 Dane, 'The Maps of Sovereignty', 966. 
their churches. ${ }^{196}$ The religious organizations' 'right to discriminate' has been exponentially expanded: first, regarding their employees in non-profit secular entities like gymnasiums (as in Amos); then in schools (Hosanna-Tabor); and now in for-profit business corporations (Hobby Lobby). Today, employees working in a religiously affiliated non-profit or in a non-religiously affiliated for-profit corporation can cost her a basic civil liberty - protection from discrimination - a right she previously enjoyed, while all other citizens retain this liberty. ${ }^{197}$

Voluntary association is a core principle of modern civil society entailing the freedom to function under your own norms and rules. The liberal-democratic state does not demand congruence of voluntary associations' procedural or substantive norms with liberal-democratic political ones. But the scope of autonomy and permissible incongruence must be determined by civil law in a liberal democracy that is protective of the equal rights of citizens, within and for association, and whatever their affiliations. No one group has a special right to 'autonomy'. The purpose of the voluntary association or non-profit organization matters, of course. But a presumptive exemption from anti-discrimination civil rights and labour law uniquely for the religious employer in for- or non-profit enterprises is antithetical to liberal democratic principles. There can be no 'no-go' areas for civil jurisdiction when it comes to ensuring that all associations comply with the public purposes and basic rights required by justice.

It is not my purpose in this paper to provide a map for deciding which mode of regulating religious associations and practices are required by liberal democratic principles or which accommodations these principles may or may not justify. ${ }^{198}$ My aim is to reveal and challenge the logic underlying the claim that religion is so special and unique that it requires a form of deference from civil authority that no other set of beliefs, practices, or associations merit. I show this claim rests on a metaphysical notion of sovereignty, a political theological conception of the corporate, and a jurisdictional logic parading as liberal pluralism but really involving a neo-medieval understanding of both society and the state that challenges democratic legitimacy and liberal principles of justice. My approach assumes that the liberal principles of justice ensured by civil law, together with democratic principles of legitimacy, trump claims to religious or church autonomy when basic rights and capabilities of individuals, harms to third parties and compelling public purposes are at stake.

I agree with James Nickel that there is no conceptual or normative need for a unique right to religious freedom: the sum of the basic liberal rights would suffice. ${ }^{199}$ Guarantees of religious freedom in constitutions or international documents protect against targeting, discrimination, and coercion of religious minori-

197 Rosenblum, 'Amos: Religious Autonomy and the Moral Uses of Pluralism'.

198 See Cohen, 'The Politics and Risks of the New Legal Pluralism in the Domain of Intimacy', 380-97, for a taxonomy of modes of regulation of religious associations by the state.

199 James Nickel, 'Who Needs Freedom of Religion?', 11. 
ties. Benign legislative accommodations that do not infringe on the rights of others or unfairly privilege religion are not necessarily antithetical to liberalism but they don't require recognition of religion's 'uniqueness'. I also agree with Cécile Laborde: in order to determine the limits of the self-determination of religious voluntary associations and affiliated non-profits and the proper scope for ethical integrity, one would have to disaggregate the concept religion itself. Only then could one specify values a liberal democratic polity must legally protect that pertain to the discrete aspects of religion - as doctrine, as an identity, as moral obligation, as a conception of the good life, as an integrated form of life, as a nomos community, and as a vulnerable class. ${ }^{200}$ I concur that basic liberal, democratic, and critical-republican principles must do the work when regulation by the civil state is at issue. Different forms of civil and religious association will require different ranges of protection depending on their purposes. But none merit being singled out as so unique and independent of considerations of civil justice that they are beyond the jurisdiction of civil law. Corporations are distinct agents under law but unlike natural persons they have no interests independent of the individuals composing, controlled and affected by them. The liberal democratic principle of equality of natural persons thus dictates that their associational rights must be limited by taking into account effects on the interests of all affected individuals and the community at large. ${ }^{201}$

Accommodation-ists bemoan the shift from jurisdiction to justice, fearing that churches, like other civil associations, will be regulated according to requirements of liberal justice. ${ }^{202}$ It is against this possibility that the resurrection of the discourse of church autonomy, corporate claims to freedom of religion, and its restoration as an autonomous jurisdictional domain has to be understood. The project is to wrest key domains of jurisdiction from the civil state, to regain unique privileges, and to block regulation protective of members' or employees' civil rights under labour and other civil law. This goes together with the strident insistence that liberal justice and the liberal state itself cannot be justified in secular terms. ${ }^{203}$ Installing corporate forms of religious-status group legal pluralism under twenty-first-century conditions is a strategy to shift the political approach to religion away from considerations of liberal justice back to jurisdiction. Only a covert reliance on a political-theological conception of the corporate on the part of today's jurisdictional pluralists would render the religious corporation immune to state regulation. The recent First Amendment decisions by the pro-corporate, states-rightist, anti-regulatory Roberts Court, when read in this light, are alarming indeed.

'Real' universal transnational religious corporate community is once again being counter-posed to the 'particularism' of the state. The autonomy of religious law

200 Cécile Laborde, 'Equal Liberty, Non-Establishment and Religious Freedom', Legal Theory 20(1) (2014): 42-77.

201 Philip Pettit, 'Two Fallacies about Corporations', ms. online

202 Smith, Disenchantment of Secular Discourse, 131.

203 Ibid. 
and the corporate 'freedom' of religious nomos communities are on the agenda everywhere. The corporate religious want to regain control over this-worldly domains: education, family law, and now even parts of corporate business law. Their critique of state sovereignty is a counter-sovereignty bid aimed at the erection of a transnationally organized religious legal pluralism free at last from the primacy of the political and democratic civil regulation by the state or by secular transnational bodies. We should not let that happen. 